Article

\title{
Synthesis and Conformational Analysis of Naphthoxazine-Fused Phenanthrene Derivatives
}

\author{
Khadija Belasri $^{1,2}$, Leila Topal ${ }^{1}$, Matthias Heydenreich ${ }^{3}{ }^{\circledR}$, Andreas Koch ${ }^{3}$, Erich Kleinpeter ${ }^{3}$, \\ Ferenc Fülöp ${ }^{1,2}$ (1) and István Szatmári ${ }^{1,2, *(1)}$ \\ 1 Institute of Pharmaceutical Chemistry and MTA-SZTE Stereochemistry Research Group, Hungarian \\ Academy of Sciences, University of Szeged, Eötvös u. 6, H-6720 Szeged, Hungary; \\ belasrikhadija15@gmail.com (K.B.); topal.leila@gmail.com (L.T.); fulop@pharm.u-szeged.hu (F.F.) \\ 2 Institute of Pharmaceutical Chemistry, University of Szeged, Interdisciplinary excellence center, \\ H-6720 Szeged, Hungary \\ 3 Department of Chemistry, University of Potsdam, Karl-Liebknecht-Str. 24-25, D-14476 Potsdam (Golm), \\ Germany; mheydenr@uni-potsdam.de (M.H.); kochi@uni-potsdam.de (A.K.); \\ ekleinp@uni-potsdam.de (E.K.) \\ * Correspondence: szatmari.istvan@pharm.u-szeged.hu; Tel.: +36-62-341-966
}

Academic Editor: Bagrat A. Shainyan

Received: 15 May 2020; Accepted: 26 May 2020; Published: 28 May 2020

\begin{abstract}
The synthesis of new phenanthr[9,10-e][1,3]oxazines was achieved by the direct coupling of 9-phenanthrol with cyclic imines in the modified $a z a$-Friedel-Crafts reaction followed by the ring closure of the resulting bifunctional aminophenanthrols with formaldehyde. Aminophenanthrol-type Mannich bases were synthesised and transformed to phenanthr[9,10-e][1,3]oxazines via $[4+2]$ cycloaddition. Detailed NMR structural analyses of the new polyheterocycles as well as conformational studies including Density Functional Theory (DFT) modelling were performed. The relative stability of ortho-quinone methides (o-QMs) was calculated, the geometries obtained were compared with the experimentally determined NMR structures, and thereby, the regioselectivity of the reactions has been assigned.
\end{abstract}

Keywords: modified Mannich reaction; cyclic imines; [4 + 2] cycloaddition; NMR spectroscopy; conformational analysis; DFT calculations

\section{Introduction}

It is known that 9-phenanthrol is one of the most attractive structural units present in a large number of biologically active compounds. It is the identified inhibitor of the transient receptor potential melastatin (TRPM) 4 channels, a $\mathrm{Ca}^{2+}$ activated non-selective cation channel whose mechanism of action remains to be determined [1-4]. Subsequent studies have proven that it modulates smooth muscle contraction in bladder and cerebral arteries, affects spontaneous activity in neurons and in the heart, and reduces lipopolysaccharide-induced cell death [5-7].

The Mannich reaction is one of the most important reactions in organic synthesis to form C-C bonds [8-10]. This synthetic pathway is widely used in the formation of secondary and tertiary amine derivatives and it is a key step in the synthesis of numerous bioactive molecules and complex natural products [11,12]. In one of the special variations of the modified Mannich reaction $(m \mathrm{MR}), 1$ - and 2-naphthol were applied as electron-rich aromatic compounds $[13,14]$. Mechanistically, the modified $a z a$-Friedel-Crafts reaction can be interpreted as a special $m \mathrm{MR}$, where electron-rich aromatic compounds such as 1- and 2-naphthol and their $\mathrm{N}$-containing analogues are reacted with a wide range of cyclic imines to furnish aminonaphthols $[15,16]$, aminoquinolinols, or aminoisoquinolinols [17- 
19]. Accordingly, our first aim was to examine the reactivity of 9-phenanthrol with different cyclic imines in the modified aza-Friedel-Crafts reaction.

Recent publications pointed out that ortho-quinone methides (o-QMs) can also be generated from Mannich bases after thermal elimination of the amino group [20]. The reactive moiety thus formed can be stabilized by reactions with different dienophiles $[14,21,22]$ or it can participate in $[4+2]$ cycloadditions with cyclic imines to form new heterocycles $[18,23,24]$. Very recently the transformation of functionalised 1-aminobenzyl-2-naphthols via [4 +2] cycloaddition has been examined [25]. It was found that the regio- and diastereoselectivity of the cycloaddition depend on the functional group of the phenyl substituent. Based on these findings, our aim was to synthesise aminobenzylphenanthrols or functionalised aminobenzylphenanthrols and to study their reactivity with cyclic imines as a novel precursor Mannich bases in [4 + 2] cycloaddition. Finally, we wanted to explore both the structure and conformational behaviour of the novel polyheterocycles by NMR spectroscopy and accompanying theoretical quantum chemical $(\mathrm{QC})$ calculations.

\section{Results}

\subsection{Synthesis}

To examine the possibility of the extension of 9-phenanthrol (1) in the modified aza-Friedel-Crafts reaction, 1 was reacted with 1.5 equiv. of 3,4-dihydroisoquinoline (2) [26] (Scheme 1) under neat conditions at $80{ }^{\circ} \mathrm{C}$. After a reaction time of $120 \mathrm{~min}$, the desired product (3) was isolated only with a yield of $10 \%$. By increasing the temperature to $100{ }^{\circ} \mathrm{C}$ the yield of 3 increased slightly to $19 \%$. Yields found under these conditions were not satisfactory and the appearance of side products was also observed. By changing the solvent to acetonitrile, treatment at reflux temperature $\left(90^{\circ} \mathrm{C}\right)$ afforded 3 in an isolated yield of $49 \%$. The product was easily separated out from the reaction mixture that is acetonitrile proved to be an optimal solvent. To further improve the yield, the reaction was repeated under microwave (MW) conditions. In this case the reaction was driven at $100{ }^{\circ} \mathrm{C}$ and after a short reaction time (10 $\mathrm{min}$ ) 3 was isolated in a yield of $67 \%$, that could be improved to $82 \%$ by increasing the reaction time to $20 \mathrm{~min}$ (Table 1). It should be noted that the optimal workup procedure remained the filtration of the formed product from the cold reaction mixture. Subsequently, with the satisfactory optimal reaction conditions in hand, the extension possibility of the reaction was tested by using various cyclic imines, including 6,7-dihydrothieno[3,2-c]pyridine (4) [27] or 3,4-dihydro- $\beta$-carboline (6) [28]. These reactions afforded new 1-(9-phenanthrol-10-yl)-thieonopyridine 5 and 1-(9-phenanthrol-10-yl)- $\beta$-carboline 7 in yields of $92 \%$ and $76 \%$, respectively (Table 1 ).
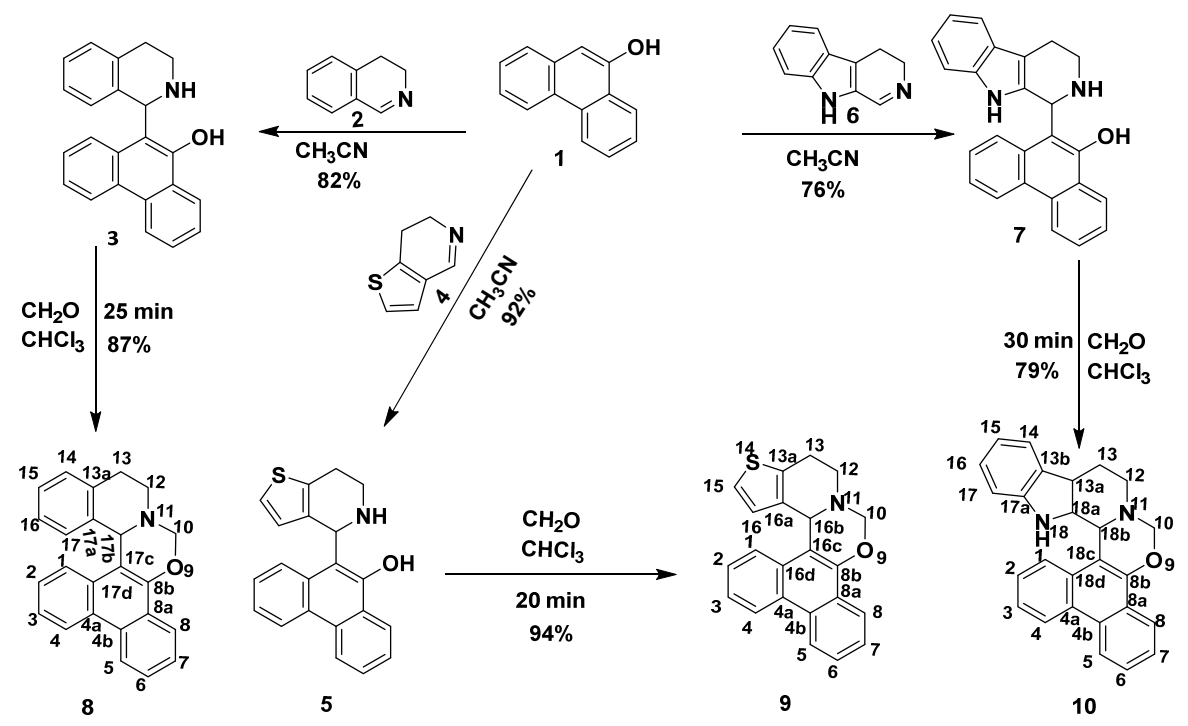

Scheme 1. Syntheses and ring closures of bifunctional compounds 3, 5 and 7. 
Table 1. Synthesis of aminophenanthrols 3, 5 and 7 under varied reaction conditions.

\begin{tabular}{cccccc}
\hline \multirow{2}{*}{ Products } & $\begin{array}{c}\text { Type of } \\
\text { Heating }\end{array}$ & Solvent & Reaction Time & Temperature & Yield (\%) \\
& Oil bath & - & $120 \mathrm{~min}$ & $80^{\circ} \mathrm{C}$ & 10 \\
& Oil bath & - & $60 \mathrm{~min}$ & $100^{\circ} \mathrm{C}$ & 19 \\
\multirow{2}{*}{3} & Oil bath & Acetonitrile & $60 \mathrm{~min}$ & $90{ }^{\circ} \mathrm{C}$ & 49 \\
& $\mathrm{MW}$ & Acetonitrile & $10 \mathrm{~min}$ & $100^{\circ} \mathrm{C}$ & 67 \\
& $\mathrm{MW}$ & Acetonitrile & $20 \mathrm{~min}$ & $100^{\circ} \mathrm{C}$ & 82 \\
\hline \multirow{2}{*}{5} & $\mathrm{MW}$ & Acetonitrile & $20 \mathrm{~min}$ & $100^{\circ} \mathrm{C}$ & 72 \\
& $\mathrm{MW}$ & Acetonitrile & $35 \mathrm{~min}$ & $100^{\circ} \mathrm{C}$ & 92 \\
\hline \multirow{2}{*}{7} & $\mathrm{MW}$ & Acetonitrile & $20 \mathrm{~min}$ & $100^{\circ} \mathrm{C}$ & 63 \\
& $\mathrm{MW}$ & Acetonitrile & $40 \mathrm{~min}$ & $100^{\circ} \mathrm{C}$ & 76 \\
\hline
\end{tabular}

In the next step, the ring closures of aminophenanthrols 3, 5, and 7 were performed with 35\% aqueous formaldehyde in $\mathrm{CHCl}_{3}$ at room temperature. Reactions completed in relatively short time and phenanthrooxazines 8-10 were isolated in excellent yields by simple crystallization from $n$-hexane.

To test aminophenanthrols in cycloaddition reaction, first the synthesis of precursor 13 was achieved by reacting 9-phenanthrol (1) with morpholine in the presence of benzaldehyde. The reaction was carried out under solvent-free conditions at $80^{\circ} \mathrm{C}$. After a 4 -h reaction, the desired 10-morpholinobenzyl-9-phenanthrol (13) was isolated by crystallization with $n$-hexane (Scheme 2).

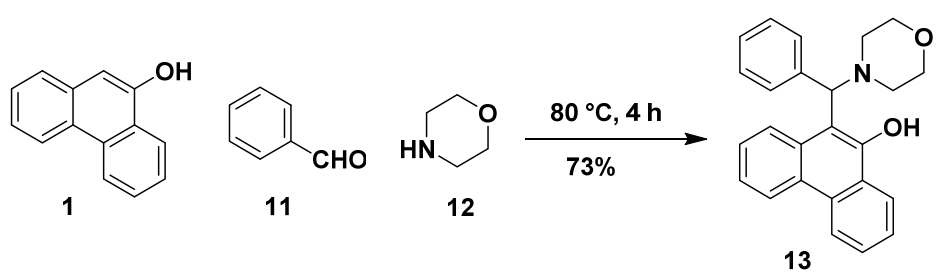

Scheme 2. Synthesis of 10-morpholinobenzyl-9-phenanthrol (13).

First, aminophenanthrol 13 was reacted with 3,4-dihydroisoquinoline 2 as dienophile. The reaction was performed in 1,4-dioxane under microwave irradiation at three different temperatures $(60,80$, and $100{ }^{\circ} \mathrm{C}$ ). In our first experiment, the reaction was performed at $60^{\circ} \mathrm{C}$ and after a relatively short reaction time the desired product (14) was isolated only in a low yield (47\%). Since the yield was not satisfactory, the reaction was repeated at 80 and $100{ }^{\circ} \mathrm{C}$. As Table 2 shows, $80^{\circ} \mathrm{C}$ and 15 min reaction time were found to be the optimal reaction conditions. The series of dienophiles was extended by using 6,7-dihydrothieno[3,2-c]pyridine 4 and 3,4-dihydro- $\beta$-carboline 6 (Scheme 3). The optimal conditions and related yields are listed in Table 2. Since two new stereogenic centres are generated during the reaction, two epimeric structures ( $\mathbf{a}$ and $\mathbf{b}$ ) can be obtained. The reaction was monitored by TLC and the compositions of the crude reaction mixtures were verified by ${ }^{1} \mathrm{H}-\mathrm{NMR}$ analysis. All reactions were found to be diastereoselective and the relative configuration of H-9a:H-17 (14), H-9a:H-16 (15) and H-9a:H-18 (16) proved to be trans, based on the detailed NMR analysis (vide infra). 
Table 2. Syntheses of phenanthr[9,10-e]oxazine derivatives (14-16) under varied reaction conditions.

\begin{tabular}{cccc}
\hline Product & Reaction Time & Temperature $\left({ }^{\circ} \mathbf{C}\right)$ & Yield (\%) \\
\hline \multirow{2}{*}{14} & \multirow{3}{*}{15 min } & 60 & 47 \\
& & 80 & 86 \\
& \multirow{3}{*}{15} & 100 & 29 \\
\hline \multirow{2}{*}{15} & & 60 & 52 \\
& \multirow{3}{*}{15} & 80 & 94 \\
& \multirow{2}{*}{15} & 100 & 37 \\
& & 60 & 21 \\
& & 80 & 76 \\
\hline
\end{tabular}
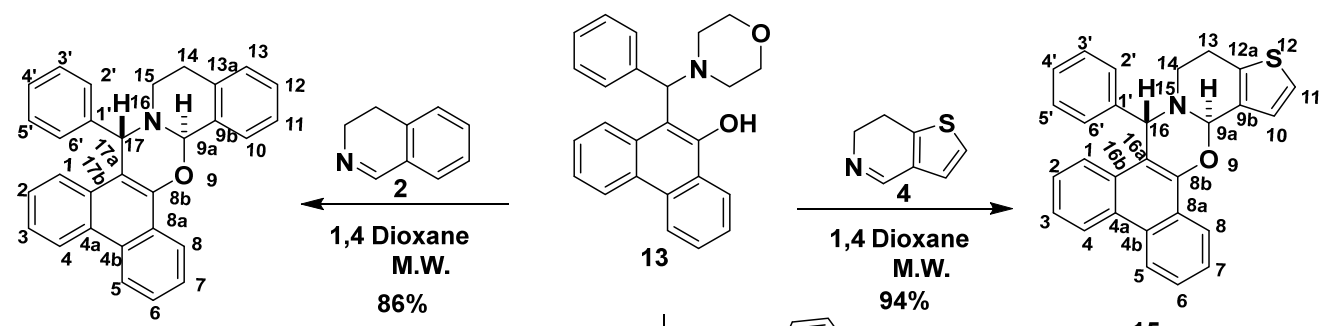

14

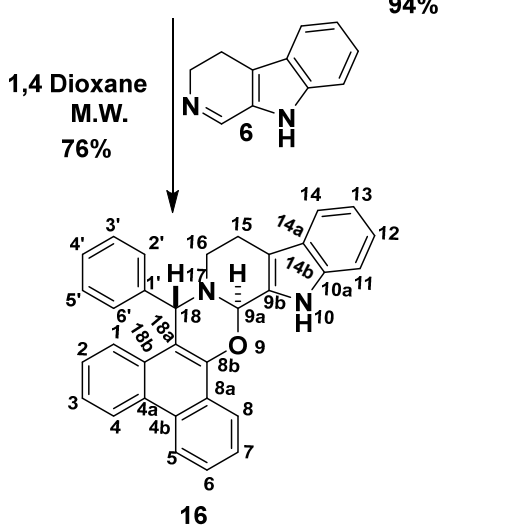

15

Scheme 3. Synthesis of phenanthr[9,10-e]oxazine derivatives (14-16).

Next, we wanted to investigate how $o$-QMs generated from functionalised aminophenanthrol derivatives can influence the [ $4+2]$ cycloaddition reaction. Accordingly, 9-phenanthrol and salicylic aldehyde were reacted in the presence of morpholine. The reaction was carried out under neat conditions at $80^{\circ} \mathrm{C}$. The characteristic spot formed according to the TLC was isolated and the NMR spectra of the formed compound confirmed the structure of 19 . Formation of the dibenzo $[a, c]$ xanthene (19) side-product can be explained by the elimination of water from diol 18. In this latter modified Mannich reaction, the availability of the nucleophile (morpholine) was postulated. Therefore, it was replaced by pyrrolidine applying again the above conditions $\left(80^{\circ} \mathrm{C}\right.$, neat). After a reaction time of $4 \mathrm{~h}$, the expected phenanthrol derivative 21 was isolated in a yield of 76\% (Scheme 4).

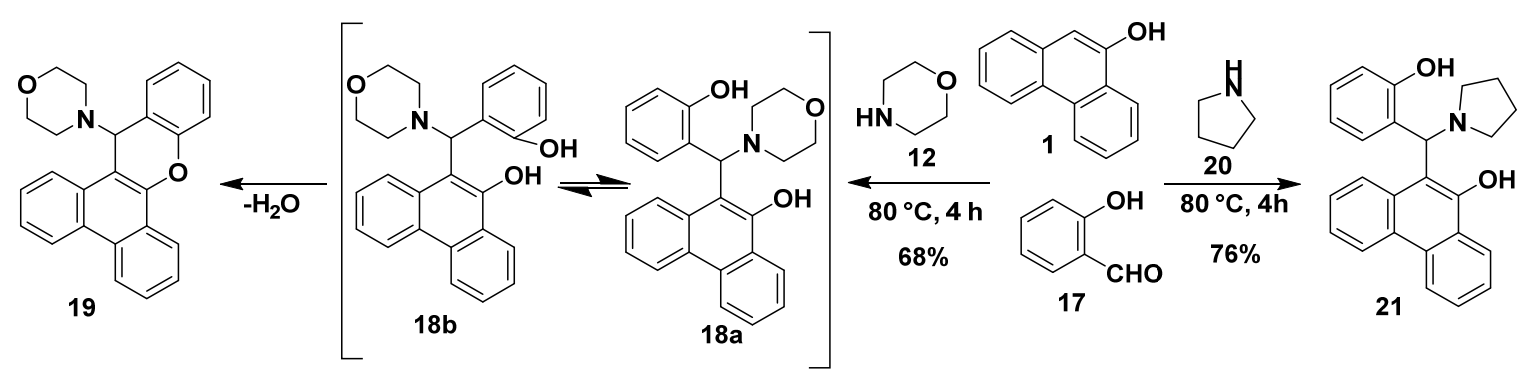

Scheme 4. Synthesis of compounds 19 and 21. 
To test the scope and limitations of the [4+2] cycloaddition, precursor 21 was first reacted with 3,4-dihydro- $\beta$-carboline as dienophile. The reaction was performed in 1,4-dioxane at three different temperatures $\left(60,80\right.$, and $\left.100^{\circ} \mathrm{C}\right)$ under microwave irradiation (Table 3). After the thermal decomposition of starting material 21, two types of 0 -QMs (22a and 22b) can be formed that can lead to the formation of two regioisomers and two diastereomers (Scheme 5) verified by ${ }^{1} \mathrm{H}-\mathrm{NMR}$ analysis of the crude reaction mixture. Then, various reaction conditions were applied as depicted in Table 3. In all cases, reactions were found to be regio- and diastereoselective. The detailed NMR analysis (vide infra) confirmed that the formed/isolated product $\mathbf{2 4 a}$ is a phenanthroxazine and the relative configuration of H-9a:H-18 is trans.

Table 3. Optimizing reaction conditions for the synthesis of $\mathbf{2 4 b}, \mathbf{2 6 b}$ and $28 \mathrm{~b}$.

\begin{tabular}{|c|c|c|c|}
\hline Products & Reaction Time & Temperature $\left({ }^{\circ} \mathrm{C}\right)$ & Yield (\%) \\
\hline \multirow{3}{*}{$\begin{array}{l}23 a, b \\
24 a, b\end{array}$} & \multirow{3}{*}{$15 \mathrm{~min}$} & 60 & 48 \\
\hline & & 80 & 85 \\
\hline & & 100 & 33 \\
\hline \multirow{3}{*}{$\begin{array}{l}25 a, b \\
26 a, b\end{array}$} & \multirow{3}{*}{$15 \mathrm{~min}$} & 60 & 28 \\
\hline & & 80 & 78 \\
\hline & & 100 & 19 \\
\hline \multirow{3}{*}{$\begin{array}{l}27 a, b \\
28 a, b\end{array}$} & \multirow{3}{*}{$15 \mathrm{~min}$} & 60 & 51 \\
\hline & & 80 & 93 \\
\hline & & 100 & 38 \\
\hline
\end{tabular}

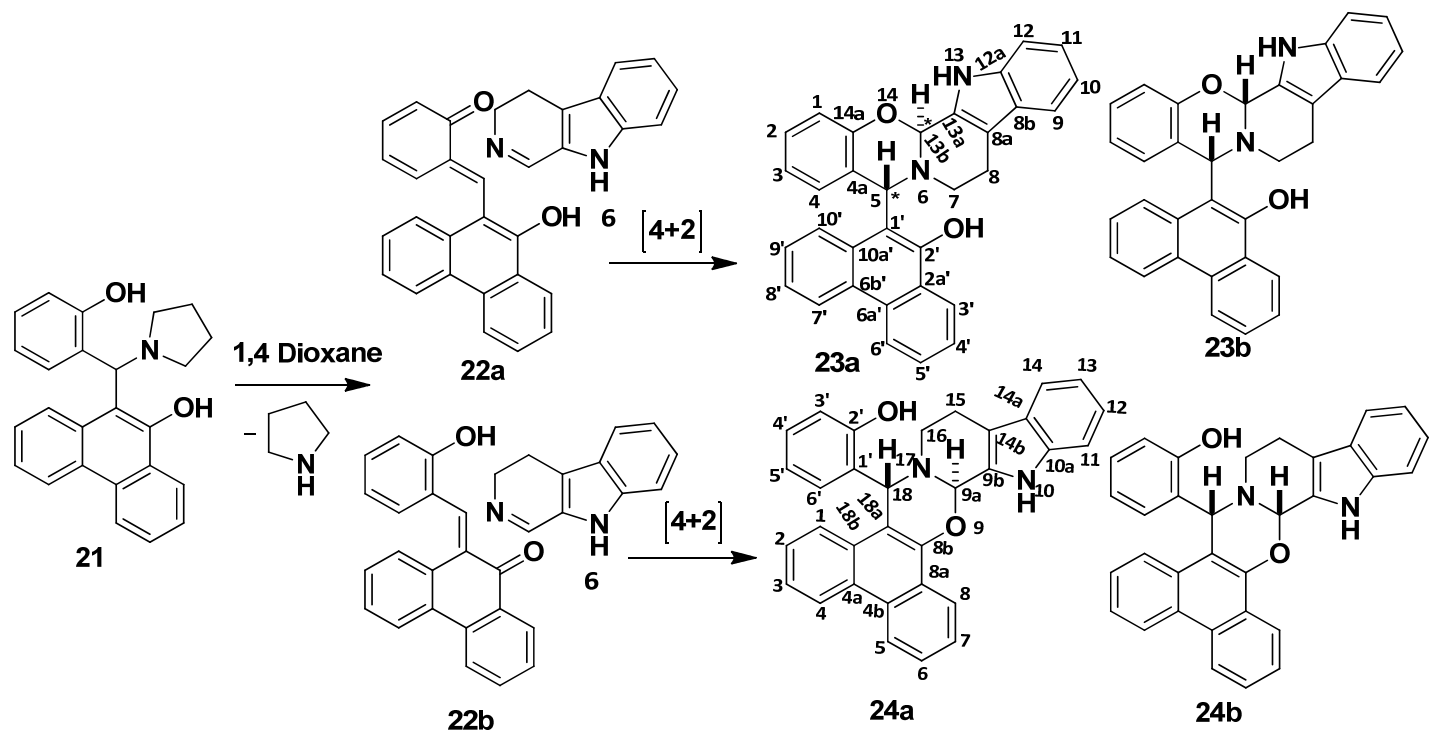

Scheme 5. $[4+2]$ Cycloaddition between 21 and 3,4-dihydro- $\beta$-carboline.

The reaction was then extended by using 3,4-dihydroisoquinoline (2) and 6,7-dihydrothieno[3,2-c]pyridine (4) as cyclic imines (Scheme 6). In these cases, similar regio- and diastereoselectivity of the reactions were proved too. Detailed NMR analysis (vide infra) adequately supported that the isolated products are trans-phenanthroxazines (26a, 28a, Scheme 6). The optimal reaction conditions together with the yields are summarised in Table 3. 


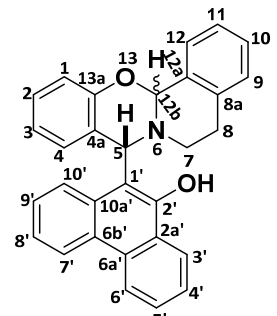

$25 \mathrm{a} ; 25 \mathrm{~b}^{5}$

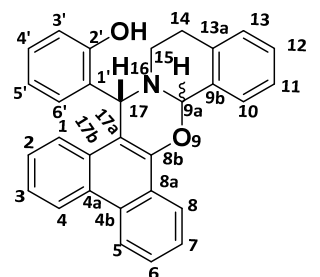

26a; $26 b$

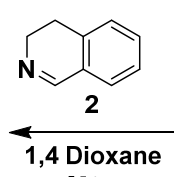

M.W.

$78 \%$
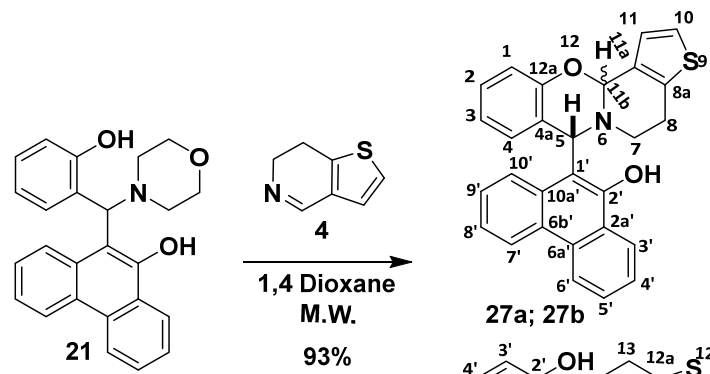

$27 a ; 27 b^{5}$
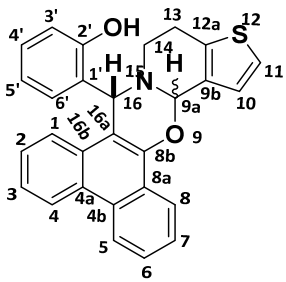

28a; 28b

Scheme 6. Reaction of functionalised aminophenanthrol 21 with cyclic imines.

\subsection{Structural and Conformational Analysis}

The complete ${ }^{1} \mathrm{H}$ and ${ }^{13} \mathrm{C}$-NMR study of both diastereomeric phenanthr[9,10-e $]$ oxazine derivatives 14-16 and regioisomeric/diastereotopic phenanthroxazine derivatives 24a, 26a, and 28a showed identical stereoisomerism (only one set of NMR spectra obtained). The NMR analyses of $\beta$-carboline derivative $\mathbf{1 6}$ and thiophene compound 28a are exemplarily utilised. The same stereoisomeric results were obtained for $\mathbf{1 4}$ and $\mathbf{2 4 a}$, as well as $\mathbf{1 5}$ and 26a. For the corresponding structure elucidation, in addition to the NMR spectra (chemical shift, coupling constants, NOEs), quantum chemical calculations were also performed.

\subsection{Detailed NMR Analysis of New Phenanthr[9,10-e]Oxazine $\mathbf{1 6}$}

Determination of the relative configuration of 14-16 is based mainly on NOE interactions and their comparison with the corresponding calculated QC structures. As an example, $\beta$-carboline derivative 16 is examined (see Figure 1). Only one of the two possible diastereomers fits the experimental results: the position of methine hydrogens $\mathrm{H}-9 \mathrm{a}$ and $\mathrm{H}-18$ was always found to be trans. The complete spatial information, found with the example of $\mathbf{1 6}$, is collected in Table 4, comparing NOE results with the calculated distances from QM calculations.

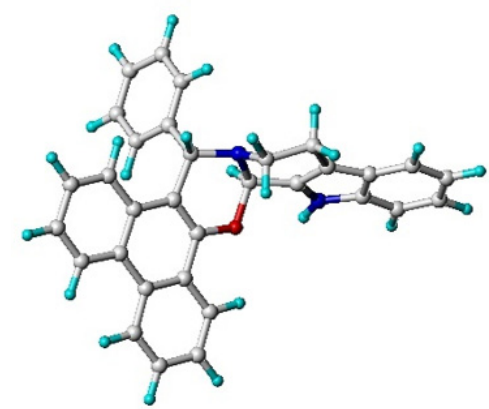

16a trans $(0.00 \mathrm{kcal} / \mathrm{mol})$

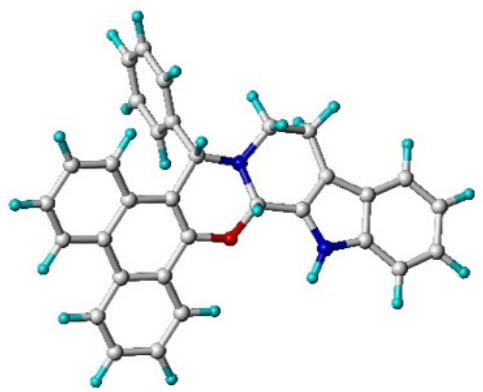

$\mathbf{1 6 b}$ cis $(3.34 \mathrm{kcal} / \mathrm{mol})$

Figure 1. Most stable structures of the diastereotopic heterocycle 16 (DFT calculated relative energies on the B3LYP/6-311G(d,p) level of theory). 
Table 4. Experimental NOE's and calculated distances in $\mathbf{1 6}$ (as DFT calculated on the B3LYP/6-311G(d,p) level of theory).

\begin{tabular}{|c|c|c|c|c|c|c|c|c|}
\hline Positions & $1 / 18$ & 9a/18 & $\begin{array}{l}18 / 16 \\
\text { (̌r-eq) }\end{array}$ & $\begin{array}{l}9 \mathrm{a} / 16 \\
(\check{\mathrm{r}}-\mathrm{eq})\end{array}$ & $\begin{array}{l}9 \mathrm{a} / 16 \\
(\check{\mathrm{r}}-\mathrm{ax})\end{array}$ & $9 a / 10$ & $\begin{array}{l}14 / 15 \\
(\check{\mathbf{r}}-\mathrm{ax})\end{array}$ & $\begin{array}{l}14 / 15 \\
\text { (řr-eq) }\end{array}$ \\
\hline Measured NOE & strong & medium & strong & weak & weak & medium & weak & medium \\
\hline Calculated & 2.2 & 3.6 & 2.2 & 4.1 & 3.8 & 2.8 & 4.3 & 2.9 \\
\hline distances d [Ĺ] & $2.2(\mathrm{cis})$ & 2.7 (cis) & 2.7(cis) & $3.8(\mathrm{cis})$ & $2.7(\mathrm{cis})$ & $3.0($ cis $)$ & 3.4(cis) & 2.9 (cis) \\
\hline $\begin{array}{l}\text { NOE-estimated } \\
\text { distances d [Ĺ }]\end{array}$ & 2.2 & 3.4 & 2.3 & 4.4 & 4.3 & 2.8 & 3.5 & 3.0 \\
\hline
\end{tabular}

$\psi$-eq (smaller signal at higher field); $\psi$-ax (the corresponding broadened signal at lower field).

\subsection{Detailed NMR Analysis of New Phenanthr[9,10-e]Oxazines $\mathbf{2 7 a}, \mathbf{b}-\mathbf{2 8 a}, \mathbf{b}$}

In analogy to previous investigations [25] and to the results of the structural analyses of 14-16 (vide supra), reactions starting from 21, in all cases, yielded trans isomers 24a, 26a, and 28a. Their NMR spectra are akin to the corresponding spectra of the compounds without an $\mathrm{OH}$ group at position 2 ' (14-16) and to compounds having a naphthalene moiety instead of phenanthrene [25].

To get the preferred stereoisomers of $\mathbf{2 8} \mathbf{a}, \mathbf{b}$, the trans/cis diastereomers of the regioisomers were calculated by the DFT method. Both the most stable structures and the corresponding energy differences are given in Figure 2. On the basis of these data, 28a could be confirmed to be the most stable structure. Energy differences around $1 \mathrm{kcal} / \mathrm{mol}$ to the next coming structure are rather unequivocal. Consequently, this structure of trans isomer 28a will be adjusted with the available experimental NMR $\left[\delta\left({ }^{1} \mathrm{H}\right) / \mathrm{ppm}\right.$, $\delta\left({ }^{13} \mathrm{C}\right) / \mathrm{ppm},{ }^{\mathrm{n}} \mathrm{H}_{\mathrm{H}, \mathrm{H}} / \mathrm{Hz}$ )] and spatial NMR information (qualitative NOE's).

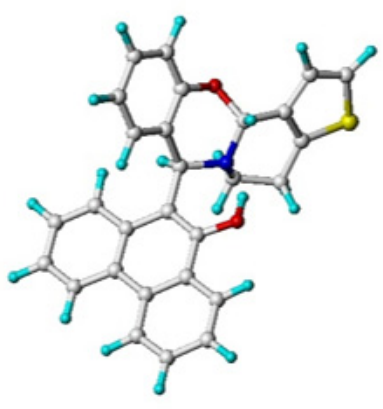

27a trans $(3.98 \mathrm{kcal} / \mathrm{mol})$

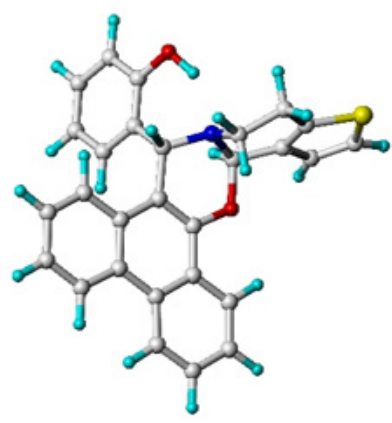

28a trans $(0.00 \mathrm{kcal} / \mathrm{mol})$

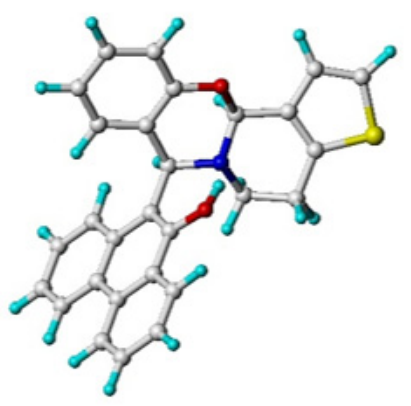

$27 \mathrm{~b}$ cis $(1.85 \mathrm{kcal} / \mathrm{mol})$

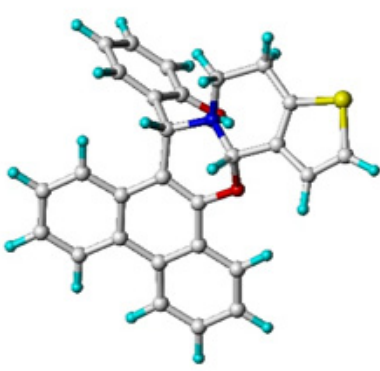

$28 \mathrm{~b}$ cis $(4.33 \mathrm{kcal} / \mathrm{mol})$

Figure 2. The most stable structures of regioisomeric heterocycles $\mathbf{2 7} \mathbf{a}, \mathbf{b}$ and $\mathbf{2 8} \mathbf{a}, \mathbf{b}$ including their trans (a) and cis (b) diastereomeric possibilities (DFT calculated relative energies on the B3LYP/6-311G(d,p) level of theory).

First, all ${ }^{1} \mathrm{H}-\mathrm{NMR}$ and ${ }^{13} \mathrm{C}-\mathrm{NMR}$ chemical shifts for 28a could be unequivocally assigned. Hereby, the two singlets of protons $\mathrm{H}-16$ and $\mathrm{H}-9 \mathrm{a}$ and the $\mathrm{AX}$ spin system of thiophene protons $\mathrm{H}-10$ and 
H-11 can serve as useful starting points. The latter is the only spin system of aromatic protons with two doublets and with characteristic ortho-coupling constant of about $5.2 \mathrm{~Hz}$. The high-field doublet (at $7.09 \mathrm{ppm}$ ) was assigned to the $\mathrm{H}-10$ proton due to the substantial NOE to tertiary proton H-9a. On the other hand, no NOE between $\mathrm{H}-10$ and the second tertiary proton (H-16) could be measured. The trans position of these two protons and, consequently, the trans stereochemistry of 28a can be proved. Furthermore, the HMBC connectivity of the same proton singlet (H-16) established the access to both the ${ }^{1} \mathrm{H}$ and ${ }^{13} \mathrm{C}$ assignments of the present aromatic moieties ((i) to C-6 ${ }^{\prime}, \mathrm{C}-1^{\prime}$, and C-2' of the phenolic, and (ii) to $\mathrm{C}-16 \mathrm{a}$ and $\mathrm{C}-8 \mathrm{~b}$ of the phenanthryl parts of the molecule), and to the piperidyl moiety via C-14. The trans stereochemistry of 28 a could be proved additionally by the strong NOEs of $\mathrm{H}-16$ to one of the H-14 protons, to the aromatic proton $\mathrm{H}-6$ ' and to one of the $\mathrm{H}-14$ protons. That is $\mathrm{H}-12 \mathrm{a}$ did not show any NOE to protons of the piperidyl ring.

The excellent agreement between the protons, proton distances, as calculated and the existence of strong NOEs in 28a can serve as an excellent further proof of the present regio- and diastereoselectivity. Similar ${ }^{1} \mathrm{H} /{ }^{13} \mathrm{C}$-NMR studies of the isoquinoline (25a,b and $\left.\mathbf{2 6} \mathbf{a}, \mathbf{b}\right)$ and $\beta$-carboline analogues $(\mathbf{2 3} \mathbf{a}, \mathbf{b}$ and $\mathbf{2 4} \mathbf{a}, \mathbf{b})$ allowed to arrive at the same conclusion. These compounds also prefer the same regioisomerism in trans configuration of $\mathbf{2 4 a}$ and $\mathbf{2 6 a}$, respectively.

\section{Materials and Methods}

\subsection{General Methods}

Melting points were determined on a Hinotek X-4 (Ningbo, China) melting point apparatus. Elemental analyses were performed with a Perkin-Elmer 2400 CHNS elemental analyzer (Waltham, MA, USA) in the Institute of Pharmaceutical Chemistry, University of Szeged. Merck Kieselgel 60F254 plates (Budapest, Hungary)were used for TLC. Microwave reactions were performed with a CEM Discover SP microwave reactor (Matthwes, NC, USA).

The starting cyclic imines 3,4-dihydroisoquinoline (2) [26], 6,7-dihydrothieno[3,2-c]pyridine (4) [27] and 4,9-dihydro- $\beta$-carboline (6) [28] were synthesised according to literature processes.

Quantum chemical calculations were performed using the Gaussian 09 program package [29] and carried out on LINUX clusters. The various different conformations and configurations of the studied compounds were optimised [30]. The B3LYP density functional method was selected for all calculations. The method is based on Becke's three-parameter hybrid functionals [31] and the correlation functional of Lee et al. [32]. All optimizations were carried out without any restriction at this B3LYP/6-311G(d,p) level of theory [33-35].

The ${ }^{1} \mathrm{H}$ and ${ }^{13} \mathrm{C}$-NMR spectra were recorded in $\mathrm{CDCl}_{3}, \mathrm{CD}_{2} \mathrm{Cl}_{2}$, or DMSO- $d_{6}$ solution in $5 \mathrm{~mm}$ tubes at room temperature on a Bruker Avance NEO spectrometer (Karlsruhe, Germany) at $400.18\left({ }^{1} \mathrm{H}\right)$ $\mathrm{MHz}$, or on a Bruker Avance spectrometer (Karlsruhe, Germany) at $500.17\left({ }^{1} \mathrm{H}\right)$ and $125.77\left({ }^{13} \mathrm{C}\right) \mathrm{MHz}$, or on a Bruker Avance III spectrometer (Karlsruhe, Germany) at $600.13\left({ }^{1} \mathrm{H}\right)$ and $150.61\left({ }^{13} \mathrm{C}\right) \mathrm{MHz}$, with the deuterium signal of the solvent as the lock and TMS as internal standard. All spectra $\left({ }^{1} \mathrm{H},{ }^{13} \mathrm{C}\right.$, gs-H,H COSY, edited HSQC, gs-HMBC and NOESY) were acquired and processed with the standard BRUKER software (TopSpin 3.6 or TopSpin 4.0).

\subsection{Procedures}

3.2.1. General Procedure for the Synthesis of Hydroxyphenanthryl-Isoquinoline, -Thienopyridine and - $\beta$-Carboline $(3,5$ and 7$)$

The mixture of the cyclic imine [3,4-dihydroisoquinoline (2), 6,7-dihydrothieno[3,2-c]pyridine (4) or 4,9-dihydro- $\beta$-carboline (6) $0.51 \mathrm{mmol}$ ] and 9-phenanthrol (1: $100 \mathrm{mg}, 0.51 \mathrm{mmol})$ in acetonitrile (5 $\mathrm{mL}$ ) was placed in a $10-\mathrm{mL}$ pressurised reaction vial and heated under microwave conditions at $100{ }^{\circ} \mathrm{C}$. After the reaction completed, the mixture was cooled down and the formed crystals were filtered and washed with cold acetonitrile $(2 \times 5 \mathrm{~mL})$. 


\section{1-(9-Hydroxyphenanthr-10-yl)-1,2,3,4-tetrahydroisoquinoline (3)}

Reaction time: $20 \mathrm{~min}$; recrystallised from $\mathrm{PPr}_{2} \mathrm{O}(5 \mathrm{~mL}) ; \mathrm{R}_{\mathrm{f}}=0.70$ ( $n$-hexane/EtOAc, $\left.2: 1\right) ; 135 \mathrm{mg}$ (82\%); white crystals; m.p.: $147-149{ }^{\circ} \mathrm{C} ;{ }^{1} \mathrm{H}-\mathrm{NMR}$ (DMSO- $\left.d_{6}, 500 \mathrm{MHz}\right): \delta 8.80(1 \mathrm{H}, \mathrm{d}, J=8.3 \mathrm{~Hz}, \mathrm{H}-4$ or H-5), $8.80(1 \mathrm{H}, \mathrm{d}, J=8.3 \mathrm{~Hz}, \mathrm{H}-4$ or H-5), 8.23(1H, d, J=8.3 Hz, H-8), $8.17(1 \mathrm{H}, \mathrm{d}, J=8.2 \mathrm{~Hz}, \mathrm{H}-1)$, $7.67(1 \mathrm{H}, \mathrm{m}, \mathrm{H}-6), 7.66(1 \mathrm{H}, \mathrm{m}, \mathrm{H}-2), 7.60(1 \mathrm{H}, \mathrm{t}, J=7.5 \mathrm{~Hz}, \mathrm{H}-7), 7.52(1 \mathrm{H}, \mathrm{t}, J=7.7 \mathrm{~Hz}, \mathrm{H}-3), 7.18(1 \mathrm{H}$, $\left.\mathrm{d}, J=7.5 \mathrm{~Hz}, \mathrm{H}-5^{\prime}\right), 7.09\left(1 \mathrm{H}, \mathrm{t}, J=7.4 \mathrm{~Hz}, \mathrm{H}-6^{\prime}\right), 6.86\left(1 \mathrm{H}, \mathrm{t}, J=7.4 \mathrm{~Hz}, \mathrm{H}-7^{\prime}\right), 6.58(1 \mathrm{H}, \mathrm{d}, J=7.9 \mathrm{~Hz}$, H-8' ), 6.10 (1H, s, H-1'), 3.44 (1H, m, H-3'), 3.20 (2H, m, H-3' , H-4' ), $2.90\left(1 \mathrm{H}, \mathrm{d}, J=14.1 \mathrm{~Hz}, \mathrm{H}-4^{\prime}\right)$; elemental analysis calcd (\%) for $\mathrm{C}_{23} \mathrm{H}_{19} \mathrm{NO}$ (323.41): C 84.89, H 5.89, N 4.30; found: C 84.82, H 5.90, N 4.26. (Figures S1-S9).

\section{4-(9-Hydroxyphenanthr-10-yl)-4,5,6,7-tetrahydrothieno[3,2-c]pyridine (5)}

Reaction time: $35 \mathrm{~min}$; recrystallised from $\mathrm{iPr} 2 \mathrm{O}(4 \mathrm{~mL}) ; \mathrm{R}_{\mathrm{f}}=0.75$ ( $n$-hexane/EtOAc, 2:1); 155 mg (92\%); Light beige crystals; m.p.: $191-188^{\circ} \mathrm{C} ;{ }^{1} \mathrm{H}-\mathrm{NMR}\left(\mathrm{DMSO}-\mathrm{d}_{6}, 500 \mathrm{MHz}\right): \delta 14.33(1 \mathrm{H}, \mathrm{d}, J=$ $7.7 \mathrm{~Hz}, \mathrm{H}-4$ or H-5), $8.78(1 \mathrm{H}, \mathrm{d}, J=7.9 \mathrm{~Hz}, \mathrm{H}-4$ or H-5), $8.19(1 \mathrm{H}, \mathrm{d}, J=8.7 \mathrm{~Hz}, \mathrm{H}-1), 8.17(1 \mathrm{H}, \mathrm{dd}, J$ $=8.2,1.2 \mathrm{~Hz}, \mathrm{H}-8), 7.66(1 \mathrm{H}, \mathrm{m}, \mathrm{H}-6), 7.65(1 \mathrm{H}, \mathrm{m}, \mathrm{H}-2), 7.60(1 \mathrm{H}, \mathrm{t}, J=7.5 \mathrm{~Hz}, \mathrm{H}-7), 7.51(1 \mathrm{H}, \mathrm{t}, J=$ $7.7 \mathrm{~Hz}, \mathrm{H}-3), 7.06\left(1 \mathrm{H}, \mathrm{d}, J=5.2 \mathrm{~Hz}, \mathrm{H}-6^{\prime}\right), 6.16\left(1 \mathrm{H}, \mathrm{d}, J=5.2 \mathrm{~Hz}, \mathrm{H}-7^{\prime}\right), 6.01\left(1 \mathrm{H}, \mathrm{s}, \mathrm{H}-1^{\prime}\right), 4.74(1 \mathrm{H}, \mathrm{br}$ s, H-2'), $3.53\left(1 \mathrm{H}, \mathrm{m}, \mathrm{H}-3^{\prime}\right), 3: 13\left(2 \mathrm{H}, \mathrm{m}, \mathrm{H}-3^{\prime}, \mathrm{H}^{\prime} 4^{\prime}\right), 2.94\left(1 \mathrm{H}, \mathrm{m}, \mathrm{H}-4^{\prime}\right)$; elemental analysis calcd (\%) for $\mathrm{C}_{21} \mathrm{H}_{17} \mathrm{NOS}$ (331.43): C 76.10, H 5.17, N 4.23; found: C 76.25, H 5.17, N 4.13 (Figures S10-S18).

1-(9-Hydroxyphenanthr-10-yl)-1,2,3,4-tetrahydro- $\beta$-carboline (7)

Reaction time: $40 \mathrm{~min}$; recrystallised from $\mathrm{iPr}_{2} \mathrm{O}(6 \mathrm{~mL}) ; \mathrm{R}_{\mathrm{f}}=0.73$ ( $n$-hexane/EtOAc, $\left.2: 1\right) ; 146 \mathrm{mg}$ (76\%); brown crystals; m.p.: $205-207^{\circ} \mathrm{C} ;{ }^{1} \mathrm{H}-\mathrm{NMR}\left(\mathrm{DMSO}-\mathrm{d}_{6}, 500 \mathrm{MHz}\right): \delta 9.76(1 \mathrm{H}, \mathrm{s}, 9-\mathrm{OH}), 8.83(1 \mathrm{H}$, $\mathrm{d}, J=8.2 \mathrm{~Hz}, \mathrm{H}-4$ or H-5), $8.81(1 \mathrm{H}, \mathrm{d}, J=8.2 \mathrm{~Hz}, \mathrm{H}-4$ or H-5), $8.29(1 \mathrm{H}, \mathrm{d}, J=8.3 \mathrm{~Hz}, \mathrm{H}-8), 8.17(1 \mathrm{H}, \mathrm{dd}$, $J=8.1,0.9 \mathrm{~Hz}, \mathrm{H}-1), 7.68(2 \mathrm{H}, \mathrm{m}, \mathrm{H}-6, \mathrm{H}-7), 7.59(1 \mathrm{H}, \mathrm{t}, J=7.6 \mathrm{~Hz}, \mathrm{H}-2), 7.55(1 \mathrm{H}, \mathrm{t}, J=7.5 \mathrm{~Hz}, \mathrm{H}-3)$, 7.44 (1H, m, H-5'); 7.15 (1H; m; H-8' ), 6.95 (2H, m, H-6' , H-7' ), $6.24\left(1 \mathrm{H}, \mathrm{s}, \mathrm{H}-1^{\prime}\right), 3.55(1 \mathrm{H}, \mathrm{dd}, J=11.5$, $\left.5.1 \mathrm{~Hz}, \mathrm{H}-3^{\prime}\right), 3.18\left(1 \mathrm{H}, \mathrm{ddd}, J=11.6,11.6,5.1 \mathrm{~Hz}, \mathrm{H}-3^{\prime}\right), 3.02\left(1 \mathrm{H}, \mathrm{m}, \mathrm{H}-4^{\prime}\right) ; 2: 87(1 \mathrm{H}, \mathrm{dd}, J=15.4 \mathrm{~Hz}$, $\mathrm{H}-4^{\prime}$ ); elemental analysis calcd (\%) for $\mathrm{C}_{25} \mathrm{H}_{20} \mathrm{~N}_{2} \mathrm{O}$ (364.45): C 82.39, H 5.53, N 7.69; found: C 82.25, $\mathrm{H}$ 5.49, N 7.72 (Figures S19-S26).

3.2.2. General Procedure for the Synthesis of

Phenanthr[9,10-e][1,3]Oxazinoisoquinoline,-Thienopyridine and - $\beta$-Carboline (8-10)

Aminophenanthrols (3, 5 and 7; $0.25 \mathrm{mmol}$ ) was dissolved in $10 \mathrm{~mL} \mathrm{CHCl}_{3}$, aqueous solution of formaldehyde (20 mg, $0.66 \mathrm{mmol}, 35 \%)$ was then added and the mixture was stirred at room temperature. The mixture was next extracted with $10 \mathrm{~mL}$ distilled water. The organic phase was collected and then dried on $\mathrm{Na}_{2} \mathrm{SO}_{4}$. The solvent was evaporated off and the residue was crystallised from n-hexane $(10 \mathrm{~mL})$.

Phenanthr[9,10-e][1,3]oxazino[4,3-a]isoquinoline (8)

Reaction time: $25 \mathrm{~min}$; recrystallised from $n$-hexane: $\mathrm{iPr}_{2} \mathrm{O}(4: 1,5 \mathrm{~mL}) ; \mathrm{R}_{\mathrm{f}}=0.65$ (n-hexane/EtOAc, 2:1); $73 \mathrm{mg}$ (87\%); Purple crystals. m.p.: $139-141{ }^{\circ} \mathrm{C}^{1} \mathrm{H}-\mathrm{NMR}\left(\mathrm{CD}_{2} \mathrm{Cl}_{2}, 500 \mathrm{MHz}\right): \delta 8.71(2 \mathrm{H}, \mathrm{m}, \mathrm{H}-4$, H-5), $8.28(1 \mathrm{H}, \mathrm{d}, J=8.1 \mathrm{~Hz}, \mathrm{H}-8), 7.73(1 \mathrm{H}, \mathrm{m}, \mathrm{H}-1), 7.70(1 \mathrm{H}, \mathrm{m}, \mathrm{H}-6), 7.63(1 \mathrm{H}, \mathrm{t}, \mathrm{J}=7.5 \mathrm{~Hz}, \mathrm{H}-7), 7.54$ $(2 \mathrm{H}, \mathrm{m}, \mathrm{H}-2, \mathrm{H}-3), 7.24(1 \mathrm{H}, \mathrm{d}, J=7.3 \mathrm{~Hz}, \mathrm{H}-14), 7.20(1 \mathrm{H}, \mathrm{t}, J=7.3 \mathrm{~Hz}, \mathrm{H}-15), 6.97(1 \mathrm{H}, \mathrm{t}, J=7.4 \mathrm{~Hz}$, $\mathrm{H}-16), 6.85=(1 \mathrm{H}, \mathrm{d}, J=7.7 \mathrm{~Hz}, \mathrm{H}-17), 5.54(1 \mathrm{H}, \mathrm{s}, \mathrm{H}-17 \mathrm{~b}), 4.76(1 \mathrm{H}, \mathrm{d}, J=7.0 \mathrm{~Hz}, \mathrm{H}-10), 4.68(1 \mathrm{H}, \mathrm{d}, J=$ $6.9 \mathrm{~Hz}, \mathrm{H}-10), 3.87$ (1H, m H-12), 2.99 (3H, m, H-12, H-13); elemental analysis calcd (\%) for $\mathrm{C}_{24} \mathrm{H}_{19} \mathrm{NO}$ (337.42): C 85.43, H 5.68, N 4.15; found: C 85.35, H 5.56, N 4.20 (Figures S27-S35).

Phenanthr[9,10-e][1,3]oxazino[4,3-a]thieno[3,2-c]pyridine (9)

Reaction time: $20 \mathrm{~min}$; recrystallised from $n$-hexane: $\mathrm{iPr}_{2} \mathrm{O}(4: 1,4 \mathrm{~mL}) ; \mathrm{R}_{\mathrm{f}}=65$ ( $n$-hexane/EtOAc, 2:1); $80 \mathrm{mg}$ (94\%); Yellow crystals. m.p.: $186-188^{\circ} \mathrm{C}^{1} \mathrm{H}-\mathrm{NMR}\left(\mathrm{CD}_{2} \mathrm{Cl}_{2}, 500 \mathrm{MHz}\right): \delta 8.70(1 \mathrm{H}, \mathrm{d}, J=$ $8.1 \mathrm{~Hz}, \mathrm{H}-4), 8.69$ (1H, d, J = 8.2 Hz, H-5), $8.26(1 \mathrm{H}, \mathrm{d}, J=8.1 \mathrm{~Hz}, \mathrm{H}-8), 7.99(1 \mathrm{H}, \mathrm{d}, J=8.1 \mathrm{~Hz}, \mathrm{H}-1)$, 
$7.69(1 \mathrm{H}, \mathrm{t}, J=7.5 \mathrm{~Hz}, \mathrm{H}-6), 7.63(2 \mathrm{H}, \mathrm{m}, \mathrm{H}-2, \mathrm{H}-7), 7.58(1 \mathrm{H}, \mathrm{t}, J=7.7 \mathrm{~Hz}, \mathrm{H}-3), 6.95(1 \mathrm{H}, \mathrm{d}, J=5.2 \mathrm{~Hz}$, H-15), $6.66(1 \mathrm{H}, \mathrm{d}, J=5.2 \mathrm{~Hz}, \mathrm{H}-16), 5.67(1 \mathrm{H}, \mathrm{s}, \mathrm{H}-16 \mathrm{~b}), 4.96(1 \mathrm{H}, \mathrm{d}, J=6.9 \mathrm{~Hz}, \mathrm{H}-10), 4.93(1 \mathrm{H}, \mathrm{d}, J=$ $6.9 \mathrm{~Hz}, \mathrm{H}-10), 3.75(1 \mathrm{H}, \mathrm{ddd}, J=14.2,12.2,6.0 \mathrm{~Hz}, \mathrm{H}-12), 3.66(1 \mathrm{H}, \mathrm{dd}, J=14.3,6.8 \mathrm{~Hz}, \mathrm{H}-12), 3.03(1 \mathrm{H}$, $\mathrm{m}, \mathrm{H}-13), 2.87(1 \mathrm{H}, \mathrm{dd}, J=17.1,5.7 \mathrm{~Hz}, \mathrm{H}-13)$; elemental analysis calcd (\%) for $\mathrm{C}_{22} \mathrm{H}_{17} \mathrm{NOS}$ (343.44): C 76.94, H 4.99, N 4.08; found: C 76.86, H 5.02, N 4.13 (Figures S36-S45).

Phenanthr[9,10-e][1,3]oxazino[4,3-a]- $\beta$-carboline (10)

Reaction time: $30 \mathrm{~min}$; recrystallised from $n$-hexane: $\mathrm{iPr}_{2} \mathrm{O}(4: 1,5 \mathrm{~mL}) ; \mathrm{R}_{\mathrm{f}}=0.60$ ( $n$-hexane/EtOAc, 2:1); $74 \mathrm{mg}$ (79\%); Dark pink crystals. m.p.: $183-185^{\circ} \mathrm{C}^{1} \mathrm{H}-\mathrm{NMR}\left(\mathrm{CD}_{2} \mathrm{Cl}_{2}, 500 \mathrm{MHz}\right): \delta 8.78(1 \mathrm{H}, \mathrm{d}, J=$ $8.2 \mathrm{~Hz}, \mathrm{H}-4), 8.71(1 \mathrm{H}, \mathrm{d}, J=8.3 \mathrm{~Hz}, \mathrm{H}-5), 8.28(1 \mathrm{H}, \mathrm{dd}, J=8.2,0.7 \mathrm{~Hz}, \mathrm{H}-8), 8.15(1 \mathrm{H}, \mathrm{d}, J=8.1 \mathrm{~Hz}, \mathrm{H}-1)$, $7.85(1 \mathrm{H}$, br s, H-18), $7.76(1 \mathrm{H}, \mathrm{t}, J=7.5 \mathrm{~Hz}, \mathrm{H}-2), 7.71(1 \mathrm{H}, \mathrm{t}, J=7.6 \mathrm{~Hz}, \mathrm{H}-6), 7.66(1 \mathrm{H}, \mathrm{t}, J=7.5 \mathrm{~Hz}$, H-3), $7.64(1 \mathrm{H}, \mathrm{t}, J=7.6 \mathrm{~Hz}, \mathrm{H}-7), 7.51(1 \mathrm{H}, \mathrm{m}, \mathrm{H}-14), 7.11(1 \mathrm{H}, \mathrm{m}, \mathrm{H}-17), 7.06$ (2H, m, H-15, H-16), 5.92 $(1 \mathrm{H}, \mathrm{s}, \mathrm{H}-18 \mathrm{~b}), 5.01(1 \mathrm{H}, \mathrm{d}, J=7.1 \mathrm{~Hz}, \mathrm{H}-10), 4.95(1 \mathrm{H}, \mathrm{d}, J=7.1 \mathrm{~Hz}, \mathrm{H}-10), 3.77$ (1H, ddd, J = 14.2, 12.0, $5.7 \mathrm{~Hz}, \mathrm{H}-12), 3.71$ (1H, dd, $J=14.3,6.3 \mathrm{~Hz}, \mathrm{H}-12), 2.99$ (1H, dddd, $J=16.2,11.9,6.7,2.4 \mathrm{~Hz}, \mathrm{H}-13), 2.83$ $(1 \mathrm{H}, \mathrm{dd}, J=16.3,5.1 \mathrm{~Hz}, \mathrm{H}-13)$; elemental analysis calcd (\%) for $\mathrm{C}_{26} \mathrm{H}_{20} \mathrm{~N}_{2} \mathrm{O}$ (376.46): C 82.95, $\mathrm{H}$ 5.36, N 7.44; found: C 83.03, H 5.45, N 7.32 (Figures S46-S56).

10-[(Phenyl)-morpholin-4-yl-methyl]-9-phenanthrol (13)

Briefly, 9-phenanthrol (1.0 g, $5.13 \mathrm{mmol})$, benzaldehyde $(0.54 \mathrm{~g}, 5.13 \mathrm{mmol})$, and morpholine $(0.45 \mathrm{~g}, 5.13 \mathrm{mmol})$ were stirred and heated at $80^{\circ} \mathrm{C}$ under neat conditions for $4 \mathrm{~h}$. The residue was crystallized with $n$-hexane $\left(14 \mathrm{~mL}\right.$ ) and recrystallised from iPr $\mathrm{r}_{2} \mathrm{O}(9 \mathrm{~mL}) \mathrm{R}_{\mathrm{f}}=0.75$ (n-hexane/EtOAc, 2:1); $1.38 \mathrm{~g}(73 \%)$; Light beige crystals; m.p.: $107-109{ }^{\circ} \mathrm{C} ;{ }^{1} \mathrm{H}-\mathrm{NMR}$ (DMSO-d $\left.{ }_{6}, 500 \mathrm{MHz}\right): \delta 14.37$ (1H, s, 9-OH), $8.75(1 \mathrm{H}, \mathrm{d}, J=7.6 \mathrm{~Hz}, \mathrm{H}-5), 8.71(1 \mathrm{H}, \mathrm{d}, J=7.8 \mathrm{~Hz}, \mathrm{H}-4), 8.39(1 \mathrm{H}, \mathrm{m}, \mathrm{H}-8), 8.07(1 \mathrm{H}, \mathrm{d}, J=$ $8.3 \mathrm{~Hz}, \mathrm{H}-1), 7.69\left(4 \mathrm{H}, \mathrm{m}, \mathrm{H}-6, \mathrm{H}-7, \mathrm{H}-2^{\prime}\right), 7.51(1 \mathrm{H}, \mathrm{t}, J=7.7 \mathrm{~Hz}, \mathrm{H}-2), 7.42(1 \mathrm{H}, \mathrm{t}, J=7.5 \mathrm{~Hz}, \mathrm{H}-3), 7.31$ $\left(2 \mathrm{H}, \mathrm{t}, J=7.5 \mathrm{~Hz}, \mathrm{H}-3^{\prime}\right) ; 7.23\left(1 \mathrm{H}, \mathrm{t}, J=7.3 \mathrm{~Hz}, \mathrm{H}-4^{\prime}\right), 5.45(1 \mathrm{H}, \mathrm{s}, \mathrm{H}-11), 3.72\left(4 \mathrm{H}, \mathrm{m}, \mathrm{H}-3^{\prime \prime}\right), 3.72(1 \mathrm{H}, \mathrm{m}$, H-2"); elemental analysis calcd (\%) for $\mathrm{C}_{25} \mathrm{H}_{23} \mathrm{NO}_{2}$ (369.46): C 81.27, $\mathrm{H}$ 6.28, $\mathrm{N}$ 3.79; found: $\mathrm{C} 81.31, \mathrm{H}$ 6.12, N 3.71 (Figures S57-S65).

\subsubsection{General Procedure for the Synthesis of Phenanthr[9,10-e][1,3]Oxazines $(\mathbf{1 4}, \mathbf{1 5}$ and 16)}

A mixture of the appropriate aminophenanthrol $13(60 \mathrm{mg} 0.16 \mathrm{mmol})$ and $0.13 \mathrm{mmol}$ of the cyclic imine (3,4-dihydroisoquinoline (2), 6,7-dihydrothieno[3,2-c]pyridine (4), or 4,9-dihydro- $\beta$-carboline (6)) in 1,4-dioxane $(5 \mathrm{~mL}$ ) was placed in a $10 \mathrm{~mL}$ pressurized reaction vial and heated under microwave conditions at $80^{\circ} \mathrm{C}$ for $20 \mathrm{~min}$. The solvent was removed under reduced pressure, and the residue was isolated by crystallisation with $\mathrm{MeOH}(5 \mathrm{~mL})$.

9aR*,17S*-15-(Phenyl)-phenanthr[9,10-e]oxazino[2,3-a]isoquinoline (14)

Recrystallised from $n$-hexane: $\mathrm{iPr}_{2} \mathrm{O}(2: 1,4 \mathrm{~mL}) ; \mathrm{R}_{\mathrm{f}}=0.62$ ( $n$-hexane/EtOAc, $\left.2: 1\right) ; 56 \mathrm{mg}(86 \%)$; Light yellow crystals. m.p.: $209-21{ }^{\circ} \mathrm{C}^{1} \mathrm{H}-\mathrm{NMR}\left(\mathrm{CD}_{2} \mathrm{Cl}_{2}, 500 \mathrm{MHz}\right): \delta 8.72(1 \mathrm{H}, \mathrm{d}, J=8.3 \mathrm{~Hz}, \mathrm{H}-5)$, $8.69(1 \mathrm{H}, \mathrm{d}, J=8.4 \mathrm{~Hz}, \mathrm{H}-4), 8.28(1 \mathrm{H}, \mathrm{dd}, J=8.2,0.9 \mathrm{~Hz}, \mathrm{H}-8), 7.70(1 \mathrm{H}, \mathrm{ddd}, J=8.3,7.0,1.3 \mathrm{~Hz}$, H-6), $7.61(1 \mathrm{H}, \mathrm{ddd}, J=8.1,7.0,1.1 \mathrm{~Hz}, \mathrm{H}-7)$, 7.51-7.41 (6H, m, H-1, H-2, H-3, H-13, H-2'); 7:37-7:24 (6H, m, H-10, H-11, H-12, H-3' , H-4' ), 5.83 (1H, s, H-9a), 5.49 (1H, s, H-17), 3.40 (1H, m, H-15-廿-ax), $3.31(1 \mathrm{H}, \mathrm{m}, \mathrm{H}-14-\psi$ - ax), $3.18(1 \mathrm{H}, \mathrm{dd}, J=10.4,5.7 \mathrm{~Hz}, \mathrm{H}-15-\psi-\mathrm{eq}), 2.89(1 \mathrm{H}, \mathrm{dd}, J=16.0,2.8 \mathrm{~Hz}$,

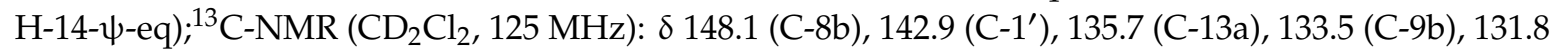
(C-4a or 4b), 131.3 (C-4a or 4b), 129.8 (C-2'), 129.3 (C-10 or 12 or 13), 129.2 (C-10 or 12 or 13), 129.1 (C-10 or 12 or 13), 128.6 (C-3'), 127.8 (C-4'), 127.5 (C-6), 127.3 (C-2), 126.9 (C-7), 126.5 (C-8a), 126.4 (C-11), 125.9 (C-17b), 124.3 (C-3), 123.7 (C-1), 123.2 (C-4), 122.9 (C-5), 122.8 (C-8), 107.8 (C-17a), 82.9 (C-9a), 63.3 (C-17), 45.9 (C-15), 29.8 (C-14); elemental analysis calcd (\%) for $\mathrm{C}_{30} \mathrm{H}_{23} \mathrm{NO}$ (413.52): C 87.14, $\mathrm{H}$ 5.61, N 3.39; found: C 87.09, H 5.45, N 3.32 (Figures S66-S78).

9aR*,16S*-16-(Phenyl)-phenanthr[9,10-e]oxazino[2,3-a]thieno[3,2-c]pyridine (15) 
Recrystallised from $n$-hexane: $\operatorname{Pr}_{2} \mathrm{O}(2: 1,4 \mathrm{~mL}) ; \mathrm{R}_{\mathrm{f}}=0.68$ (n-hexane/EtOAc, 2:1); $63 \mathrm{mg}(94 \%)$; white crystals. m.p.: $216-218{ }^{\circ} \mathrm{C}^{1} \mathrm{H}-\mathrm{NMR}\left(\mathrm{CD}_{2} \mathrm{Cl}_{2}, 500 \mathrm{MHz}\right): \delta 8.71(1 \mathrm{H}, \mathrm{d}, J=8.3 \mathrm{~Hz}, \mathrm{H}-5), 8.67(1 \mathrm{H}$, $\mathrm{d}, J=8.5 \mathrm{~Hz}, \mathrm{H}-4), 8.29(1 \mathrm{H}, \mathrm{dd}, J=8.1,0.9 \mathrm{~Hz}, \mathrm{H}-8), 7.70(1 \mathrm{H}, \mathrm{ddd}, J=8.3,7.0,1.3 \mathrm{~Hz}, \mathrm{H}-6), 7.62(1 \mathrm{H}$, ddd, J = 8.1, 7.0, 1.1 Hz, H-7), $7.47(2 \mathrm{H}, \mathrm{m}, \mathrm{H}-1, \mathrm{H}-3), 7.42(1 \mathrm{H}, \mathrm{m}, \mathrm{H}-2), 7.37\left(2 \mathrm{H}, \mathrm{m}, \mathrm{H}-2^{\prime}\right), 7.29(2 \mathrm{H}$, $\left.\mathrm{m}, \mathrm{H}-3^{\prime}\right), 7.25\left(1 \mathrm{H}, \mathrm{m}, \mathrm{H}-4^{\prime}\right), 7.21(1 \mathrm{H}, \mathrm{d}, J=5.2 \mathrm{~Hz}, \mathrm{H}-11), 7.11(1 \mathrm{H}, \mathrm{d}, J=5.2 \mathrm{~Hz}, \mathrm{H}-10), 5.83(1 \mathrm{H}, \mathrm{s}$,

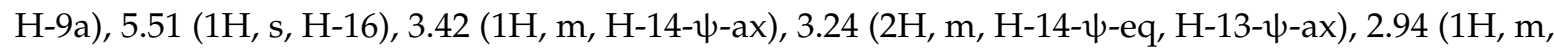

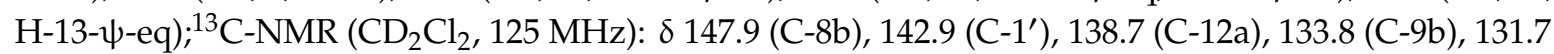
(C-4a), 131.3 (C-4b), 129.8 (C-2'), 128.6 (C-3'), 127.9 (C-4'), 127.6 (C-6), 127.3 (C-2), 126.9 (C-7), 126.5 (C-8a), 126.3 (C-10), 125.8 (C-16b), 124.3 (C-3), 123.8 (C-1), 123.6 (C-11), 123.2 (C-4), 122.8 (C-5. 8), 107.8 (C-16a), 79.6 (C-9a), 62.9 (C-16), 46.7 (C-14), 26.5 (C-13); elemental analysis calcd (\%) for $\mathrm{C}_{28} \mathrm{H}_{21} \mathrm{NOS}$ (419.54): C 80.16, H 5.05, N 3.34; found: C 83.10, H 5.15, N 3.32 (Figures S79-S91).

\section{9aR*,18S*-19-(Phenyl)-phenanthr[9,10-e]oxazino[2,3-a]- $\beta$-carboline (16)}

Recrystallised from $n$-hexane: $\mathrm{iPr}_{2} \mathrm{O}(2: 1,4 \mathrm{~mL}) ; \mathrm{R}_{\mathrm{f}}=0.70$ (n-hexane/EtOAc, 2:1); $55 \mathrm{mg}(76 \%)$; Light yellow crystals. m.p.: $180-182{ }^{\circ} \mathrm{C}{ }^{1} \mathrm{H}-\mathrm{NMR}\left(\mathrm{CD}_{2} \mathrm{Cl}_{2}, 500 \mathrm{MHz}\right): \delta 8.72(1 \mathrm{H}, J=8.3 \mathrm{~Hz}, \mathrm{H}-5), 8.68$ $(1 \mathrm{H}, \mathrm{d}, J=7.9 \mathrm{~Hz}, \mathrm{H}-4), 8.31(1 \mathrm{H}, \mathrm{br} \mathrm{s}, \mathrm{H}-10), 8.30(1 \mathrm{H}, \mathrm{d}, J=8.3 \mathrm{~Hz}, \mathrm{H}-8), 7.70(1 \mathrm{H}, \mathrm{ddd}, J=8.3,7.0$, $1.3 \mathrm{~Hz}, \mathrm{H}-6), 7.61(1 \mathrm{H}, \mathrm{m}, \mathrm{H}-7), 7.58(1 \mathrm{H}, \mathrm{d}, J=8.1 \mathrm{~Hz}, \mathrm{H}-14), 7.51(1 \mathrm{H}, \mathrm{m}, \mathrm{H}-1), 7.49(1 \mathrm{H}, \mathrm{m}, \mathrm{H}-3), 7.45$ $(1 \mathrm{H}, \mathrm{m}, \mathrm{H}-2), 7.42(1 \mathrm{H}, \mathrm{m}, \mathrm{H}-11), 7.41\left(2 \mathrm{H}, \mathrm{m}, \mathrm{H}-2^{\prime}\right), 7.30\left(2 \mathrm{H}, \mathrm{m}, \mathrm{H}-3^{\prime}\right), 7.27\left(1 \mathrm{H}, \mathrm{m}, \mathrm{H}-4^{\prime}\right), 7.23(1 \mathrm{H}$, ddd, $J=8.2,7.1,1.1 \mathrm{~Hz}, \mathrm{H}-12), 7.14(1 \mathrm{H}, \mathrm{t}, J=7.5 \mathrm{~Hz}, \mathrm{H}-13), 5.98(1 \mathrm{H}, \mathrm{s}, \mathrm{H}-9 \mathrm{a}), 5.58(1 \mathrm{H}, \mathrm{s}, \mathrm{H}-18), 3.46$ $(1 \mathrm{H}, \mathrm{m}, \mathrm{H}-16-\psi$-ax), 3.32 (1H, dd, $J=10.9,5.5 \mathrm{~Hz}, \mathrm{H}-16-\psi$-eq), $3.13(1 \mathrm{H}, \mathrm{ddd}, J=15.5,11.8,5.9 \mathrm{~Hz}$, H-15- $\psi$-ax), 2.89 (1H, ddd, $J=15.4,4.2,1.3 \mathrm{~Hz}, \mathrm{H}-15-\psi$-eq) ${ }^{13} \mathrm{C}-\mathrm{NMR}\left(\mathrm{CD}_{2} \mathrm{Cl}_{2}, 125 \mathrm{MHz}\right): \delta 47,6(\mathrm{C}-8 \mathrm{~b})$, 142,8 (C-1'), 136,9 (C-10a), 131,7 (C-4a), 131,3 (C-4b), 130,9 (C-9b), 129,8 (C-2'), 128,7 (C-3'), 128,0 (C-4'), 127,6 (C-6), 127,4 (C-2), 126,9 (C-7), 126,6 (C-8a or 14a), 126,5 (C-8a or 14a), 125,8 (C-18b), 124,4 (C-3), 123,6 (C-1), 123,3 (C-4), 123,1 (C-12), 122,8 (C-5), 122,7 (C-8), 120,0 (C-13), 119,4 (C-14), 111,8 (C-11), 111,5 (C-14b), 108,2 (C-18a), 78,7 (C-9a), 62,8 (C-18), 47,3 (C-16), 22,6 (C-15); elemental analysis calcd (\%) for $\mathrm{C}_{32} \mathrm{H}_{26} \mathrm{~N}_{2} \mathrm{O}$ (454.57): C 84.55, H 5.77, N 6.16; found: C 84.49, H 5.67, N 6.21 (Figures S92-S104).

\section{4-Morpholin-4-yl-dibenzo[a,c]xanthene (19)}

Briefly, 9-phenanthrol (100. mg, $0.51 \mathrm{mmol})$, salicylic aldehyde (62 mg, $0.51 \mathrm{mmol})$, and morpholine (44 mg, $0.51 \mathrm{mmol}$ ) were stirred and heated at $80{ }^{\circ} \mathrm{C}$ under neat conditions for $4 \mathrm{~h}$. The residue was crystallised with $\mathrm{iPr}_{2} \mathrm{O}(15 \mathrm{~mL})$ and recrystallised from $n$-hexane: EtOAc $(10 \mathrm{~mL} ; 10: 1) \mathrm{R}_{\mathrm{f}}=0.65$ ( $n$-hexane/EtOAc, 2:1); $127 \mathrm{mg}(68 \%)$; Browne crystals; m.p.: $176-178{ }^{\circ} \mathrm{C} ;{ }^{1} \mathrm{H}-\mathrm{NMR}\left(\mathrm{CDCl}_{3}, 500 \mathrm{MHz}\right)$ : $\delta 8.68(2 \mathrm{H}, \mathrm{m}, \mathrm{H} 4, \mathrm{H}-5), 8.58(1 \mathrm{H}, \mathrm{m}, \mathrm{H}-1), 8.22(1 \mathrm{H}, \mathrm{d}, J=7.5 \mathrm{~Hz}, \mathrm{H}-8), 7.71(1 \mathrm{H}, \mathrm{m}, \mathrm{H}-2), 7.66(2 \mathrm{H}$, m, H-3, H-7), 7.60 (1H, m, H-6), 7.40 (3H, m, H-11, H-12, H-14), 7.23 (1H, m, H-13), 5.52 (1H, s, H-15), $3.52\left(4 \mathrm{H}, \mathrm{m}, \mathrm{H}-2^{\prime}\right), 2.52\left(2 \mathrm{H}, \mathrm{m} \mathrm{H}-3^{\prime}\right), 2.40\left(2 \mathrm{H}, \mathrm{m} \mathrm{H}-3^{\prime}\right) ;{ }^{13} \mathrm{C}-\mathrm{NMR}\left(\mathrm{CDCl}_{3}, 125 \mathrm{MHz}\right) \delta 153.0(\mathrm{C}-10 \mathrm{a})$, 147.2 (C-9), 131.3 (C-4a or C-4b), 131.2 (C-4a or C-4b), 130.0 (C-14), 128.8 (C-12), 128.3 (C-15b), 127.7 (C-2 or C-3 or C-7), 127.2 (C-2 or C-3 or C-7), 127.0 (C-2 or C-3 or C-7), 125.2 (C-6), 124.6 (C-8a), 124.5 (C-8), 123.2 (C-13), 123.0 (C-1 or C-4 or C-5), 122.8 (C-1 or C-4 or C-5), 122.7 (C-1 or C-4 or C-5), 117.6 (C-14a), 116.5 (C-11), 110.5 (C-15a), 67.5 (C-3'), 57.7 (C-15), 48.7 (C-2');. elemental analysis calcd (\%) for $\mathrm{C}_{25} \mathrm{H}_{21} \mathrm{NO}_{2}$ (367.45): C 81.72, H 5.76, N 3.81; found: C 81.34, H 5.65, N 3.77 (Figures S105-S113).

10-[(2-Hydroxyphenyl)-pyrrolidin-1-yl-methyl]-9-phenanthrol (21)

Briefly, 9-phenanthrol (500 mg, $2.56 \mathrm{mmol})$, salicylic aldehyde ( $312 \mathrm{mg}, 2.56 \mathrm{mmol})$, and pyrrolidine $\left(182 \mathrm{mg}, 2.56 \mathrm{mmol}\right.$ ) were stirred and heated at $80^{\circ} \mathrm{C}$ under neat conditions for $4 \mathrm{~h}$. The residue was crystallised with $n$-hexane $\left(16 \mathrm{~mL}\right.$ ) and recrystallised from $\operatorname{Pr}_{2} \mathrm{O}(11 \mathrm{~mL}) \mathrm{R}_{\mathrm{f}}=0.70$ (n-hexane/EtOAc, 2:1); $718 \mathrm{mg}$ (76\%); Light beige crystals; m.p.: $172-174{ }^{\circ} \mathrm{C} ;{ }^{1} \mathrm{H}-\mathrm{NMR}$ (DMSO-d $\left.6,500 \mathrm{MHz}\right): \delta 15.32$ $(1 \mathrm{H}, \mathrm{br} \mathrm{s}, \mathrm{OH}), 10.12(1 \mathrm{H}, \mathrm{br} \mathrm{s}, \mathrm{OH}), 8.74(1 \mathrm{H}, \mathrm{d}, J=8.4 \mathrm{~Hz}, \mathrm{H}-5), 8.68(1 \mathrm{H}, \mathrm{d}, J=8.1 \mathrm{~Hz}, \mathrm{H}-4), 8.38$ $(1 \mathrm{H}, \mathrm{d}, J=8.5 \mathrm{~Hz}, \mathrm{H}-8), 7.94(1 \mathrm{H}, \mathrm{d}, J=8.3 \mathrm{~Hz}, \mathrm{H}-1), 7.67(2 \mathrm{H}, \mathrm{m}, \mathrm{H}-6, \mathrm{H}-7), 7.45(1 \mathrm{H}, \mathrm{t}, J=7.5 \mathrm{~Hz}$, H-2), $7.38\left(2 \mathrm{H}, \mathrm{m}, \mathrm{H}-3, \mathrm{H}-6^{\prime}\right), 7.04\left(1 \mathrm{H}, \mathrm{t}, J=7.4 \mathrm{~Hz}, \mathrm{H}-4^{\prime}\right), 6.91\left(1 \mathrm{H}, \mathrm{d}, J=8.1 \mathrm{~Hz}, \mathrm{H}-3^{\prime}\right), 6.66(1 \mathrm{H}, \mathrm{t}, J=$ $\left.7.4 \mathrm{~Hz}, \mathrm{H}-5^{\prime}\right), 5.82(1 \mathrm{H}, \mathrm{s}, \mathrm{H}-11), 3.16$ (2H, m, H-2"), 2.66 (2H, m, H-3"), $2.49\left(2 \mathrm{H}, \mathrm{m}, \mathrm{H}-3^{\prime \prime}\right), 2.40$ (2H, m, H-2"); ${ }^{13}$ C-NMR (DMSO-d 6 , 125 MHz): $\delta 154.3$ (C-2'), 151.9 (C-9), 131.3 (C-4a), 130.3 (C-4b), 128.7 (2C, 
C-4', C-6' $), 126.9$ (C-8a), 126.9 (2C, C-2, C-6), 126.2 (C-7), 124.9 (C-10a), 123.0 (C-4), 122.9 (C-3), 122.6 (C-8), 122.4 (C-5), 121.5 (C-1), 119.7 (C-5'), 115.5 (C-3'), 112.4 (C-10), 61.1 (C-11), 54.1 (C-2"), 49.6 (C-3"); elemental analysis calcd (\%) for $\mathrm{C}_{25} \mathrm{H}_{23} \mathrm{NO}_{2}$ (369.46): C 81.27, $\mathrm{H}$ 6.28, $\mathrm{N}$ 3.79; found: $\mathrm{C} 81.31, \mathrm{H} 6.15, \mathrm{~N}$ 3.76 (Figures S114-S125).

\subsubsection{General Procedure for the Synthesis of Phenanthr[9,10-e][1,3]Oxazines $(\mathbf{2 4}, \mathbf{2 6}$ and $\mathbf{2 8})$}

The mixture of aminophenanthrol $21(50 \mathrm{mg} 0.13 \mathrm{mmol}$ ) and $0.13 \mathrm{mmol}$ of the correspondent cyclic imine (3,4-dihydroisoquinoline (2), 6,7-dihydrothieno[3,2-c]pyridine (4), or 4,9-dihydro- $\beta$-carboline (6))_was dissolved in 1,4-dioxane $(5 \mathrm{~mL})$ and placed in a $10 \mathrm{~mL}$ pressurized reaction vial. The mixture was heated at $80^{\circ} \mathrm{C}$ for $15 \mathrm{~min}$ under microwave conditions. The solvent was removed in vacuo, and the residue was isolated by crystallisation with $\mathrm{MeOH}(5 \mathrm{~mL})$.

\section{9aR*,18S*-19-(2-Hydroxyphenyl)-phenanthr[9,10-e]oxazino[2,3-a]- $\beta$-carboline (24)}

Recrystallised from $\mathrm{iPr}_{2} \mathrm{O}(7 \mathrm{~mL}) ; \mathrm{R}_{\mathrm{f}}=0.38$ (n-hexane/EtOAc, 2:1); $47 \mathrm{mg}(78 \%)$. Brown crystals; m.p.: $163-165{ }^{\circ} \mathrm{C}^{1} \mathrm{H}-\mathrm{NMR}\left(\mathrm{CDCl}_{3}, 500 \mathrm{MHz}\right): \delta 8.69(2 \mathrm{H}, \mathrm{br} \mathrm{s}, \mathrm{H}-4$ and $\mathrm{H}-5), 8.21(2 \mathrm{H}, \mathrm{br} \mathrm{s}, \mathrm{H}-8$ and H-10), 7.69 (1H, t, J = 7.1 Hz, H-6), $7.577 .54(5 \mathrm{H}, \mathrm{m}, \mathrm{H}-1, \mathrm{H}-2, \mathrm{H}-3, \mathrm{H}-7$ and H-14), $7.41(1 \mathrm{H}, \mathrm{d}, J=$ $7.8 \mathrm{~Hz}, \mathrm{H}-11), 7.16\left(2 \mathrm{H}, \mathrm{m}, \mathrm{H}-13\right.$ and $\left.\mathrm{H}-4^{\prime}\right), 6.95\left(1 \mathrm{H}, \mathrm{d}, J=7.7 \mathrm{~Hz}, \mathrm{H}-3^{\prime}\right), 6.64\left(2 \mathrm{H}, \mathrm{br} \mathrm{s}, \mathrm{H}-5^{\prime}\right.$ and $\left.\mathrm{H}-6^{\prime}\right)$,

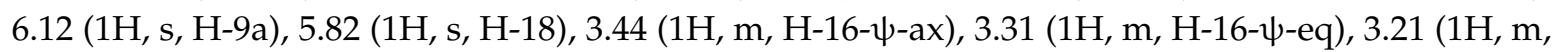

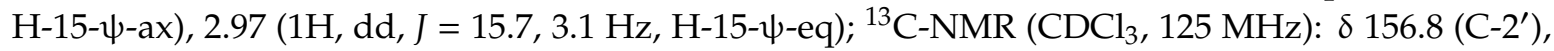
146.6 (C-8b), 136.8 (C-10a), 131.5 (C-4a or 4b), 131.4 (C-4a or 4b), 131.0 (C-6'), 129.9 (C-9b), 129.8 (C-4'), 127.8 (C-6 or C-2), 127.7 (C-6 or C-2), 126.8 (C-7), 126.4 (C-14a or C-8a), 126.3 (C-14a or C-8a), 125.5 (C-18b), 125.2 (C-1'), 124.7 (C-3), 123.4 (C-12), 123.2 (C-1. 5), 122.7 (C-8 or C-4), 122.6 (C-8 or C-4), 120.3 (C-13), 120.1 (C-5'), 119.4 (C-14), 117.7 (C-3'), 111.7 (C-11), 110.9 (C-14b), 106.0 (C-18a), 77.7 (C-9a), 60.7 (C-18), 45.4 (C-16), 22.4 (C-15); elemental analysis calcd (\%) for $\mathrm{C}_{32} \mathrm{H}_{24} \mathrm{~N}_{2} \mathrm{O}_{2}$ (468.56): C 82.03, $\mathrm{H}$ 5.16, N 5.98; found: C 82.12, H 5.09, N 5.82 (Figures S126-S139).

9aR*,17S*-15-(2-Hydroxyphenyl)-phenanthr[9,10-e]oxazino[2,3-a]isoquinoline (26)

Recrystallised from iPr $\mathrm{O}_{2}(5 \mathrm{~mL}) ; \mathrm{R}_{\mathrm{f}}=0.35$ (-n-hexane/EtOAc, 2:1); $47 \mathrm{mg}(85 \%)$. Light beige crystals; m.p.: $194-196{ }^{\circ} \mathrm{C}^{1} \mathrm{H}-\mathrm{NMR}\left(\mathrm{CDCl}_{3}, 500 \mathrm{MHz}\right): \delta 9.67\left(1 \mathrm{H}, \mathrm{br} \mathrm{s}, 2^{\prime}-\mathrm{OH}\right) 8.68(2 \mathrm{H}, \mathrm{m}, \mathrm{H}-4$ and H-6), $8.22(1 \mathrm{H}, \mathrm{d}, J=8.2 \mathrm{~Hz}, \mathrm{H}-8), 7.68(1 \mathrm{H}, \mathrm{d}, J=7.6 \mathrm{~Hz}, \mathrm{H}-6), 7.53(4 \mathrm{H}, \mathrm{m}, \mathrm{H}-1, \mathrm{H}-2, \mathrm{H}-3$ and H-7), $7.41(1 \mathrm{H}, \mathrm{d}, J=7.5 \mathrm{~Hz}, \mathrm{H}-10), 7.37(1 \mathrm{H}, \mathrm{t}, J=7.6 \mathrm{~Hz}, \mathrm{H}-12), 7.31(1 \mathrm{H}, \mathrm{t}, J=7.4 \mathrm{~Hz}, \mathrm{H}-11), 7.24(1 \mathrm{H}, \mathrm{m}$, H-13), $7.19\left(1 \mathrm{H}, \mathrm{m}, \mathrm{H}-4^{\prime}\right), 6.95\left(1 \mathrm{H}, \mathrm{d}, J=8.1 \mathrm{~Hz}, \mathrm{H}-3^{\prime}\right), 6.66\left(2 \mathrm{H}, \mathrm{m}, \mathrm{H}-5^{\prime}\right.$ and H-6' $), 5.96(1 \mathrm{H}, \mathrm{s}, \mathrm{H}-9 \mathrm{a})$,

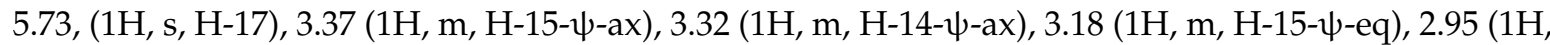
m, H-14-廿-eq); ${ }^{13} \mathrm{C}-\mathrm{NMR}\left(\mathrm{CDCl}_{3}, 125 \mathrm{MHz}\right): \delta$ (C-147.1 (C-8b), 134.3 (C-13a), 132.7 (C-9b), 131.6 (C-4a or C-4b), 131.4 (C-4a or C-4b), 131.2 (C-6'), 129.7 (C-4'), 129.5 (C-12), 129.3 (C-10), 129.0 (C-13), 127.7 (C-6), 127.6 (C-2), 126.8 (C-7), 126.7 (C-11), 126.4 (C-8a), 125.7 (C-17b), 125.4 (C-1'), 124.5 (C-3), 123.3 (C-1), 123.2 (C-4 or C-5), 122.9 (C-8), 122.6 (C-4 or C-5), 120.1 (C-5'), 117.6 (C-3'), 105.6 (C-17a), 81.9 (C-9a), 61.1 (C-17), 44.0 (C-15), 29.4 (C-14); elemental analysis calcd (\%) for $\mathrm{C}_{30} \mathrm{H}_{23} \mathrm{NO}_{2}$ (429.52): C 83.89, H 5.40, N 3.26; found: C 83.78, H 5.35, N 3.29 (Figures S140-S152).

\section{9aR*,16S*-16-(2-Hydroxyphenyl)-phenanthr[9,10-e]oxazino[2,3-a]thieno[3,2-c]pyridine (28)}

Recrystallised from $\mathrm{PPr}_{2} \mathrm{O}(4 \mathrm{~mL}) ; \mathrm{R}_{\mathrm{f}}=0.40$ ( $n$-hexane/EtOAc, 2:1); $52 \mathrm{mg}(93 \%)$. Light beige crystals; m.p.: $181-183{ }^{\circ} \mathrm{C}^{1} \mathrm{H}-\mathrm{NMR}\left(\mathrm{CDCl}_{3}, 500 \mathrm{MHz}\right): \delta 9.65\left(1 \mathrm{H}\right.$, br s, $\left.2^{\prime}-\mathrm{OH}\right), 8.69(2 \mathrm{H}, \mathrm{m}, \mathrm{H}-4, \mathrm{H}-5)$, $8.25(1 \mathrm{H}, \mathrm{d}, J=8.1 \mathrm{~Hz}, \mathrm{H}-8), 7.69(1 \mathrm{H}, \mathrm{t}, J=7.5 \mathrm{~Hz}, \mathrm{H}-6), 7.60(1 \mathrm{H}, \mathrm{m}, \mathrm{H}-7), 7.55(1 \mathrm{H}, \mathrm{m}, \mathrm{H}-1), 7.53(1 \mathrm{H}$, $\mathrm{m}, \mathrm{H}-3), 7.50(1 \mathrm{H}, \mathrm{m}, \mathrm{H}-2), 7.22(1 \mathrm{H}, \mathrm{d}, J=5.3 \mathrm{~Hz}, \mathrm{H}-11), 7.19\left(1 \mathrm{H}, \mathrm{m}, \mathrm{H}-4^{\prime}\right) ; 7: 09(1 \mathrm{H}, \mathrm{d}, J=5: 1 \mathrm{~Hz}$, H-10), 6:96 (1H, d, J = 8:0 Hz, H-3'), $6.65\left(1 \mathrm{H}, \mathrm{m}, \mathrm{H}-5^{\prime}\right), 6.63\left(1 \mathrm{H}, \mathrm{m}, \mathrm{H}-6^{\prime}\right), 5.98$ (1H, s, H-9a), 5.77

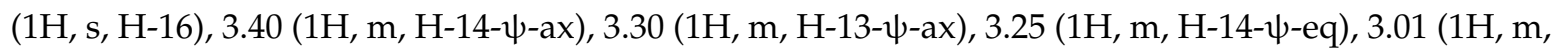

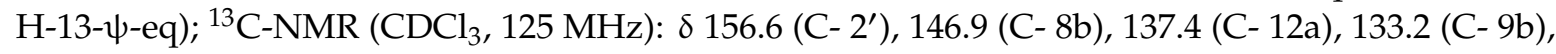
131.6 (C- 4a or C-4b), 131.4 (C- 4a or C-4b), 131.1 (C- 6'), 129.7 (C- 4'), 127.7 (C- 6), 127.6 (C- 2), 126.8 (C7), 126.4 (C- 8a), 126.2 (C- 10), 125.6 (C- 16b or C-1'), 125.3 (C- 16b or C-1'), 124.6 (C- 3), 124.2 (C- 11), 
123.2 (C- 5), 123.2 (C- 10), 122.8 (C- 4 or C-8), 122.6 (C- 4 or C-8), 120.1 (C- 5'), 117.6 (C- 3'), 105.5 (C16a), 78.7 (C- 9a), 60.7 (C- 16), 44.8 (C- 14), 26.2 (C- 13); elemental analysis calcd (\%) for $\mathrm{C}_{28} \mathrm{H}_{21} \mathrm{NO}_{2} \mathrm{~S}$ (435.54): C 77.22, H 4.86, N 3.22; found: C 77.12, H 4.75, N 3.31 (Figures S153-S165).

\section{Conclusions}

Herein, 9-phenanthrol, a unique electron-rich aromatic compound, was tested in the modified $a z a$-Friedel-Crafts reaction. The reactions of 3,4-dihydroisoquinoline, 6,7-dihydrothieno[3,2-c]pyridine or 3,4-dihydro- $\beta$-carboline as cyclic imines led to the formation of the corresponding bifunctional phenanthrol derivatives that were further transformed to the new phenanthr[9,10-e][1,3]oxazines (8-10). Furthermore, 9-phenanthrol was aminoalkylated by using morpholine in the presence of benzaldehyde: The functionalised aminophenanthrol (21) could only be synthesised by using salicylic aldehyde in the presence of pyrrolidine. Morpholine in this latter modified Mannich reaction led to the formation of 14-morpholinyl-dibenzo[a,c]xanthene (19). Phenanthrol-based bifunctional Mannich products were further tested in [4 2] cycloaddition by using 3,4-dihydroisoquinoline, 6,7-dihydrothieno[3,2-c]pyridine or 3,4-dihydro- $\beta$-carboline as dienophiles. The regio- and diastereoselectivity of the reactions were proved by NMR spectroscopy and supported by DFT calculations. All products were found to have trans-configuration (14-16, 24a, 26a, and 28a). Applying functionalised aminophenanthrol precursors in [4 +2] cycloaddition, the reactions regioselectively led to the formation of new phenanthr[9,10-e][1,3]oxazines (24a, 26a, and 28a) in good yields.

Supplementary Materials: Supplementary materials are available online: Figures S1-S165.

Author Contributions: I.S., K.B., and F.F. planned and designed the project. K.B., L.T., and I.S. performed the syntheses. E.K., M.H., and A.K. characterized the synthesised compounds. K.B., F.F., E.K., and I.S. prepared the manuscript for publication. All authors discussed the results and commented on the manuscript. All authors have read and agreed to the published version of the manuscript.

Funding: This research received no external funding.

Acknowledgments: This research is part of Khadija Belasri's PhD thesis. The authors' thanks are due to the Hungarian Research Foundation (OTKA No. K-129037); Ministry of National Economy, National Research Development and Innovation Office [GINOP-2.3.2-15-2016-00038]; the EU-funded Hungarian Grant [EFOP-3.6.1-16-2016-00008]; Ministry of Human Capacities, Hungary grant, TUDFO/47138-1/2019.

Conflicts of Interest: The authors declare no conflict of interest. The funders had no role in the design of the study; in the collection, analyses, or interpretation of data, in the writing of the manuscript, or in the decision to publish the results.

\section{References}

1. Grand, T.; Demion, M.; Norez, C.; Mettey, Y.; Launay, P.; Becq, F.; Bois, P.; Guinamard, R. 9-Phenanthrol Inhibits Human TRPM4 but not TRPM5 Cationic Channels. Br. J. Pharmacol. 2008, 153, 1697-1705. [CrossRef] [PubMed]

2. Guinamard, R.; Hof, T.; Del Negro, C.A. The TRPM4 Channel Inhibitor 9-Phenanthrol. Br. J. Pharmacol. 2014, 171, 1600-1613. [CrossRef] [PubMed]

3. Cho, C.H.; Lee, Y.S.; Kim, E.; Hwang, E.M.; Park, J.Y. Physiological Functions of the TRPM4 Channels via Protein Interactions. BMB Reports 2015, 48, 1-5. [CrossRef] [PubMed]

4. Gonzales, A.L.; Amberg, G.C.; Earley, S. $\mathrm{Ca}^{2+}$ Release from the Sarcoplasmic Reticulum is Required for Sustained TRPM4 Activity in Cerebral Artery Smooth Muscle Cells. Am. J. Physiol. Cell. Physiol. 2010, 299, C279-C288. [CrossRef]

5. Parajuli, S.P.; Hristov, K.L.; Sullivan, M.N.; Xin, W.; Smith, A.C.; Earley, S.; Malysz, J.; Petkov, G.V. Control of Urinary Bladder Smooth Muscle Excitability by the TRPM4 Channel Modulator 9-Phenanthrol. Channels 2013, 7, 537-540. [CrossRef]

6. Becerra, A.; Echeverría, C.; Varela, D.; Sarmiento, D.; Armisén, R.; Nuñez-Villena, F.; Montecinos, M.; Simon, F. Transient Receptor Potential Melastatin 4 Inhibition Prevents Lipopolysaccharide-Induced Endothelial Cell Death. Cardiovasc. Res. 2011, 91, 677-684. [CrossRef] 
7. Hou, J.; Fei, Y.; Li, W.; Chen, Y.; Wang, Q.; Xiao, Y.; Wang, Y.; Li, Y. The Transient Receptor Potential Melastatin 4 Channel Inhibitor 9-Phenanthrol Modulates Cardiac Sodium Channel. Br. J. Pharmacol. 2018, 175, 4325-4337. [CrossRef]

8. Bur, S.K.; Martin, S.F. Vinylogous Mannich Reactions: Selectivity and Synthetic Utility. Tetrahedron 2001, 57, 3221-3242. [CrossRef]

9. Speckamp, W.N.; Moolenaar, M.J. New Developments in the Chemistry of N-Acyliminium Ions and Related Intermediates. Tetrahedron 2000, 56, 3817-3856. [CrossRef]

10. Arend, M.; Westermann, B.; Risch, N. Modern Variants of the Mannich Reaction. Angew. Chem. Int. Ed. Engl. 1998, 37, 1045-1070. [CrossRef]

11. Liras, S.; Davoren, J.E.; Bordner, J. An Approach to the Skeleton of the Securinega Alkaloids. The Total Synthesis of ( \pm )-Securinine. Org. Lett. 2001, 3, 703-706. [CrossRef] [PubMed]

12. Ito, M.; Clark, C.W.; Mortimore, M.; Goh, J.B.; Martin, S.F. Biogenetically Inspired Approach to the Strychnos Alkaloids. Concise Syntheses of ( \pm )-Akuammicine and ( \pm -Strychnine. J. Am. Chem. Soc. 2001, 123, 8003-8010. [CrossRef] [PubMed]

13. Szatmári, I.; Fülöp, F. Syntheses and Transformations of 1-( $\alpha$-Aminobenzyl)-2-Naphthol Derivatives. Curr. Org. Synth. 2004, 1, 155-165. [CrossRef]

14. Szatmári, I.; Fülöp, F. Syntheses, Transformations and Applications of Aminonaphthol Derivatives Prepared via Modified Mannich Reactions. Tetrahedron 2013, 69, 1255-1278. [CrossRef]

15. MacLeod, P.D.; Li, Z.; Feng, J.; Li, C.J. Solvent-Free Direct aza-Friedel-Crafts Reactions between 3,4-Dihydroisoquinoline and 1- or 2-Naphthols. Tetrahedron Lett. 2006, 47, 6791-6794. [CrossRef]

16. Heydenreich, M.; Koch, A.; Klod, S.; Szatmári, I.; Fülöp, F.; Kleinpeter, E. Synthesis and Conformational Analysis of Naphth[1' $\left.2^{\prime}: 5,6\right][1,3]$ oxazino[3,2-c] [1,3]benzoxazine and Naphth[1',2':5,6][1,3]oxazino[3,4-c][1,3]benzoxazine Derivatives. Tetrahedron 2006, 62, 11081-11089. [CrossRef]

17. Heydenreich, M.; Koch, A.; Szatmári, I.; Fülöp, F.; Kleinpeter, E. Synthesis and Conformational Analysis of Naphth[1,2-e][1,3]oxazino[4,3-a][1,3]isoquinoline and Naphth[2,1-e][1,3]oxazino[4,3-a]isoquinoline Derivatives. Tetrahedron 2008, 64, 7378-7385. [CrossRef]

18. Szatmári, I.; Barta, P.; Tóth, G.; Balázs, A.; Halász, J.; Fülöp, F. Synthesis and Conformational Behaviour of Enantiomeric Naphthoxazinoquinoxalinone Derivatives. Eur. J. Org. Chem. 2017, 5537-5545.

19. Barta, P.; Szatmári, I.; Fülöp, F.; Heydenreich, M.; Koch, A.; Kleinpeter, E. Synthesis and Stereochemistry of New Naphth[1,3]oxazino[3,2-a]benzazepine and Naphth[1,3]oxazino[3,2-e]thienopyridine Derivatives. Tetrahedron. 2016, 72, 2402-2410. [CrossRef]

20. Barta, P.; Fülöp, F.; Szatmári, I. Mannich Base-Connected Syntheses Mediated by Ortho-Quinone Methides. Beilstein J. Org. Chem. 2018, 14, 560-575. [CrossRef]

21. Osyanin, V.A.; Osipov, D.V.; Klimochkin, Y.N. Convenient One-Step Synthesis of 4-Unsubstituted 2-Amino-4H-chromene-2-carbonitriles and 5-Unsubstituted 5H-chromeno[2,3- $b$ ]pyridine-3-carbonitriles From Quaternary Ammonium salts. Tetrahedron 2012, 68, 5612-5618. [CrossRef]

22. Pettigrew, J.D.; Freeman, R.P.; Wilson, P.D. Total Synthesis of ()-Xyloketal D and its Enantiomer Confirmation of Absolute Stereochemistry. Can. J. Chem. 2004, 82, 1640-1648. [CrossRef]

23. Szatmári, I.; Fülöp, F. Simple Access to Pentacyclic Oxazinoisoquinolines via an Unexpected Transformation of Aminomethylnaphthols. Tetrahedron Lett. 2011, 52, 4440-4442. [CrossRef]

24. Szatmári, I.; Barta, P.; Csámpai, A.; Fülöp, F. Synthesis and Detailed Conformational Analysis of New Naphthoxazino[2,3-a]benz[c]azepine and Naphthoxazino[2,3-a]thieno[3,2-c]pyridine Derivatives. Tetrahedron 2017, 73, 4790-4804. [CrossRef]

25. Szatmári, I.; Belasri, K.; Heydenreich, M.; Koch, A.; Kleinpeter, E.; Fülöp, F. Ortho-Quinone Methide Driven Synthesis of New O,N- or N,N-Heterocycles. ChemistryOpen. 2019, 8, 961-971. [CrossRef]

26. Szatmári, I.; Sas, I.; Fülöp, F. Catalyst-Free Coupling of Indole Derivatives with 3,4-Dihydroisoquinoline and Related Compounds. Tetrahedron Lett. 2013, 54, 5069-5071. [CrossRef]

27. Herz, W.; Tsai, L. Sulfur analogs of isoquinolines. IV. The Pictet-Gams Reaction and Attempts to Prepare Analogs of Papaverine1,2. J. Chem. Soc. 1955, 77, 3529-3533. [CrossRef]

28. Chen, Z.; Hu, G.; Li, D.; Chen, J.; Li, Y.; Zhou, H.; Xie, Y. Synthesis and Vasodilator Effects of Rutaecarpine Analogues which Might be Involved Transient Receptor Potential Vanilloid Subfamily, Member 1 (TRPV1). Bioorg. Med. Chem. 2009, 17, 2351-2359. [CrossRef] 
29. Frisch, M.J.; Trucks, G.W.; Schlegel, H.B.; Scuseria, G.E.; Robb, M.A.; Cheeseman, J.R.; Scalmani, G.; Barone, V.; Mennucci, B.; Petersson, G.A.; et al. Gaussian 09; (Revision A.02); Gaussian, Inc.: Wallingford, CT, USA, 2009.

30. Becke, A.D.A. Density-Functional Thermochemistry. III. The Role of Exact Exchange. J. Chem. Phys. 1993, 98, 5648-5652. [CrossRef]

31. Lee, C.; Yang, W.; Parr, R.G. Development of the Colle-Salvetti Correlation-Energy Formula into a Functional of the Electron Density. Phys. Rev. B 1988, 37, 785-789. [CrossRef]

32. Hehre, W.J.; Radom, L.; von Rague Schleyer, P.; Pople, J. Ab Initio Molecular Orbital Theory; Wiley: New York, NY, USA, 1986.

33. Becke, A.D. A New Mixing of Hartree-Fock and Local Density-Functional Theories. J. Chem. Phys. 1993, 98, 1372-1492. [CrossRef]

34. Ditchfield, R. Self-Consistent Perturbation Theory of Diamagnetism. Mol. Phys. 1974, 27, 789-807. [CrossRef]

35. Cheeseman, G.G.W.; Trucks, T.A.; Keith, M.J. A Comparison of Models for Calculating Nuclear Magnetic Resonance Shielding Tensors. J. Chem. Phys. 1996, 104, 5497-5509. [CrossRef]

Sample Availability: Samples of the compounds are not available.

(C) 2020 by the authors. Licensee MDPI, Basel, Switzerland. This article is an open access article distributed under the terms and conditions of the Creative Commons Attribution (CC BY) license (http://creativecommons.org/licenses/by/4.0/). 